\title{
Evaluation of water resources around Barapukuria coal mine industrial area, Dinajpur, Bangladesh
}

\author{
M. Farhad Howladar • Pulok Kanti Deb • \\ A. T. M. Shahidul Huqe Muzemder $\cdot$ Mushfique Ahmed
}

Received: 7 January 2014/ Accepted: 21 May 2014/Published online: 15 July 2014

(C) The Author(s) 2014. This article is published with open access at Springerlink.com

\begin{abstract}
Water is a very important natural resource which can be utilized in renewable or non-renewable forms but before utilizing, the evaluation of the quality of this resource is crucial for a particular use. However, the problems of water quality are more severe in areas where the mining and mineral processes' industries are present. In mining processes, several classes of wastes are produced which may turn into ultimately the sources of water quality and environmental degradation. In consequences, the evaluations of water quality for livestock, drinking, irrigation purposes and environmental implications have been carried out around the Barapukuria Coal Mining Industry under different methods and techniques such as primarily the field investigation; secondly the laboratory chemical analysis and thirdly justified the suitability of the laboratory analysis with statistical representation and correlation matrix, Schoeller plot, Piper's Trilinear diagram, Expanded Durov diagram, Wilcox diagram, US salinity diagram, Doneen's chart and others. The results of all surface and ground water samples analysis show that the characteristics and concentrations of all the major physical and chemical parameters such as $\mathrm{pH}, \mathrm{EC}, \mathrm{TDS}, \mathrm{Na}^{+}, \mathrm{K}^{+}, \mathrm{Ca}^{2+}$, $\mathrm{Mg}^{2+}, \mathrm{Fe}^{\text {total }}, \mathrm{Cl}^{-}, \mathrm{HCO}_{3}{ }^{-}, \mathrm{CO}_{3}{ }^{2-}$ and $\mathrm{SO}_{4}{ }^{2-}$ are varied from one sample to other but well analogous with the WHO and EQS standard limit for all purposes in the area where the abundance of
\end{abstract}

\section{F. Howladar $(\bowtie)$. P. K. Deb .}

A. T. M. S. H. Muzemder - M. Ahmed

Department of Petroleum and Mining Engineering, Shahjalal

University of Science and Technology, Sylhet 3114, Bangladesh

e-mail: farhadpme@gmail.com

P. K. Deb

e-mail: pulokpme@gmail.com

A. T. M. S. H. Muzemder

e-mail: shahidulpme@gmail.com

M. Ahmed

e-mail: mushfique1957@gmail.com the major ions is as follows: $\mathrm{Ca}^{2+}>\mathrm{Na}^{+}>\mathrm{Mg}^{2+}>\mathrm{K}^{+}>$ $\mathrm{Fe}^{\text {total }}=\mathrm{HCO}_{3}{ }^{-}>\mathrm{SO}_{4}{ }^{2-}>\mathrm{Cl}^{-}>\mathrm{CO}_{3}{ }^{2-}$. The graphical exposition of analytical data demonstrates two major hydrochemical facies for example: calcium-bicarbonate $\left(\mathrm{Ca}^{2+}\right.$ $\left.\mathrm{HCO}_{3}{ }^{-}\right)$and magnesium-bicarbonate $\left(\mathrm{Mg}^{2+}-\mathrm{HCO}_{3}{ }^{-}\right)$type facies which directly support the shallow recently recharged alkaline water around the industry. The calculated values for the evaluation classification of water based on TDS, $\mathrm{Na} \%, \mathrm{EC}, \mathrm{SAR}$, $\mathrm{PI}, \mathrm{RSC}, \mathrm{MH}$, and TH replicate good to excellent use of water for livestock, drinking and irrigation activities except in some cases. For example, the high hardness in both water samples specifies the active hydraulic relation between surface and groundwater. Moreover, the statistical application and interpretation exhibit a good positive correlation among most of the water constituents which might be the indicator of having tightly grouped, precise homogeneous good-quality water resources around the mining industry. Finally from the environmental degradation point of view, it can be implied that there are no significant parameters or factors observed which are much badly effective on environment except very few cases. Thus, this research strongly recommends for monitoring the water quality in every 6 months or annually around this industry which might be positive for keeping the safe environment and healthy production of the coal mine.

Keywords Barapukuria coal mine - Quality of water . Livestock · Drinking and irrigation - Statistical correlation matrix $\cdot$ Environmental implication

\section{Introduction}

Coal-mining operations either by underground or open-cut mining is the most recognizable environmental problem everywhere in the world while it modifies the physical, chemical and biological parameters of the environment 
around the mining area. In fact, it has far-reaching impacts on human being civilization and ecological unit. As we know that coal mine drainage ranges widely in composition from acidic to alkaline, typically with high concentration of sulfate $\left(\mathrm{SO}_{4}\right)$, iron $(\mathrm{Fe})$, manganese $(\mathrm{Mn})$ and aluminum $(\mathrm{Al})$ as well as some common elements like calcium (Ca), sodium $(\mathrm{Na})$, potassium $(\mathrm{K})$ and magnesium $(\mathrm{Mg})$, which can fatally degrade the aquatic habitat and the quality of water supplies because of toxicity, corrosion, encrustation and other effects from dissolved constituents. The waste from mine is well recognized as a cause of landscape disturbance (Bian et al. 2009) as being highly impactful to water resources (Meck et al. 2006; Dinelli et al. 2001; Ribet et al. 1995) and as a cause of social and economic problems (Schellenbach and Krekeler 2012; Palmer et al. 2010; Davis and Duffy 2009; Burns 2005). In the study area, the quality of coal is bituminous to sub-bituminous located in the lower Gondwana formation where there are a large number of faults, joints, bedding fissures, weathered zones and well-developed vertical tensile cracks filled with mud and pyrite films (Wardell 1991). The iron disulfide minerals such as pyrite $\left(\mathrm{FeS}_{2}\right)$ and less commonly marcasite $\left(\mathrm{FeS}_{2}\right)$ are the principal sulfur-bearing minerals in bituminous coal (Davis 1981; Hawkins 1984). Hence, because of its wide distribution in coal and overburden rocks, especially of fluvial water origin, pyrite may be recognized as the major source of acidic drainage in the mine as well as this part of Bangladesh (Uddin 2003). Thus, understanding the characteristics of mine drainage as well as water bodies is important for environmental monitoring and understanding pollution pathways in the environment (Krekeler and Kearns 2008; Dold and Fontboté 2002; Hudson et al. 1999; Foster et al. 1998; Davis et al. 1993). However, the groundwater is the major source of water supply for drinking, cooking and irrigation purposes in the study area. In this case, the knowledge on hydrochemical and geochemical characteristics is more important to assess the ground and surface water quality for understanding its suitability for different purposes. Therefore, the prime endeavor of this study is to evaluate the hydrochemical and geochemical characteristics of surface and groundwater for different purposes by field measurement, laboratory analysis and so on which will further facilitate better use of these precious water resources, and finally will assist the better management strategies for present and future environment around the mining area.

Brief out line about the study area

The study area BCM is located in the Parbatipur Upazila, Dinajpur district, and north-west part of Bangladesh. This area is included in the survey of Bangladesh topographic sheet no. 78C/14 (scale 1:50,000) which lies between the latitudes $23^{\circ} 31^{\prime} 45^{\prime \prime}$ and $23^{\circ} 33^{\prime} 05^{\prime \prime} \mathrm{N}$ and the longitudes $88^{\circ} 57^{\prime} 48^{\prime \prime}$ and $88^{\circ} 58^{\prime} 53^{\prime \prime} \mathrm{E}$ (Fig. 1). The area is crisscrossed by a number of streams under three rivers namely the Khorkhori, the Jamuna (local name) and the Ghirnai. Most of the streams are locally originated and are of locally filled by rainwater. From long period, the local people used various sources of water for agricultural purposes before the development of BCM and, on the other hand, currently using huge amount of coal mine inrush discharge water for agricultural purposes especially for irrigation (Uddin 2003). The study area is drained in the western side by the Khorkhori River, which flows almost in north-south direction; another big river of local name, the Jamuna flowing in the western side of the river Khorkhori; and the river Ghirnai flowing through the north-eastern side of the study area, which remains almost, dry during the winter season and becomes navigable in the rainy season (Wardell 1991). The population density of the study area is about 685 people per sq $\mathrm{km}$. Most of the inhabitants are Muslims and then Hindus. A few Santal families are living in the area. Most of the people are engaged in agricultural works, while others are in the trade and different professional jobs. Recently, many of them earn their living from coal minerelated works (Alam et al. 2011).

\section{Geologic setting}

From the sense of regional geological setting, Bangladesh is situated at the junction of three lithospheric plates such as the Indian plate, the Eurasian plate, and the Burmese sub-plate which are the three major tectonic zones in Bangladesh. These three zones (Fig. 2) are (1) a platform flank zone in the west, the Dinajpur Shield and Platform; (2) a central deeper basin, the Bengal Basin; and (3) the folded belt in the east, identified as the Chittagong-Tripura Fold Belt (Khan 1991; Khan and Chouhan 1996; Alam et al. 2003). Apiece of these regions is famed with a sole tectonic and stratigraphic records (Islam 2009; Alam et al. 2003). The BCM Basin is located in the Dinajpur Shield in Bangladesh and is bounded by Himalayan Foredeep to the north, the Shillong Shield/Platform to the east, and the Indian Peninsular Shield to the west. The Garo-Rajmahal gap lies between the exposed Peninsular Shield and the Shillong Shield, which corresponds to a shallow buried basement ridge named as the Platform flank zone (Desikacher 1974; Khan 1991). For the most part the Gondwana coal basins, including Barapukuria, Phulbari, Khalaspir, Dighipara, are positioned within the Bangladesh part of the Garo-Rajmahal gap which is locally recognized as the 'Rangpur Saddle' (Uddin and Islam 1992; Bakr et al. 1996; Islam and Islam 2005; Islam 2009). The Rangpur Saddle is a possible connection between Indian Platform and Shillong Massif with the thinnest sedimentary cover over the 


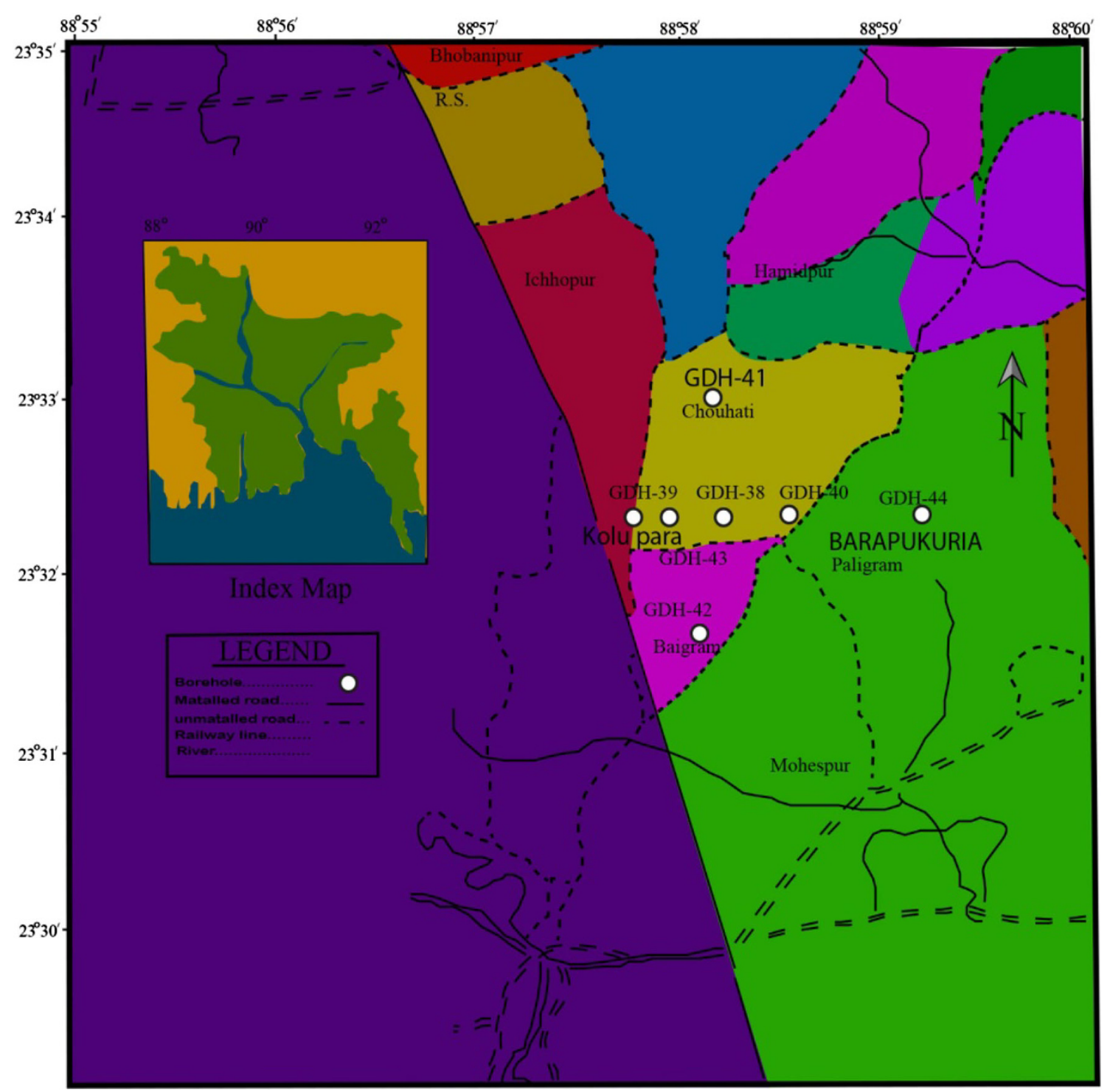

Fig. 1 Location map of the BCM, Bangladesh modified after (CMC 1994; Howladar 2012)

basement of about $128 \mathrm{~m}$ at Madhyapara. The width of the Saddle is $97 \mathrm{~km}$, which slopes both sides towards north and south forming an oval-shaped body (Zaher and Rahman 1980). The northern slope of the Rangpur Saddle (Dinajpur Slope) is about $64 \mathrm{~km}$ wide and slopes towards the SubHimalayan Foredeep, and this part is separated from the stable platform by a series of faulting. Two prominent of them trend towards east-west and the others take a sudden south-eastward swing (Khan 1991; Khan and Rahman 1992). However, the presences of intrusive bodies are inferred from records of few small magnetic anomalies in the area. The southern slope of the Rangpur Saddle (Bogra Slope) is 64-129 km wide and extends up to Hinge Zone. The inclination of basement is gentle up to Bogra, which increases further southeastwards. In this area, Gondwana sediment was deposited in the faulted troughs or subsiding basins in the Basement Complex (Zaher and Rahman 1980).

\section{Hydrogeological settings}

Considering the hydrogeologic setting of the BCM, it should be pointed out that this mine is belonging to a much complex hydrogeological condition than other area in Bangladesh. In fact, the principal constraints on the design of the BCM relate to the great thickness (average $36 \mathrm{~m}$ ) of seam, the presence of massive Gondwana sandstones and unconsolidated Dupi Tila formation (Wardell 1991). The later formation represents a major aquifer over the whole mine area with thousands of sq $\mathrm{km}$ of aerial extension. It is at least $100 \mathrm{~m}$ in thickness reaching $185 \mathrm{~m}$ in the southern part of the mine area and extends from beneath a shallow 


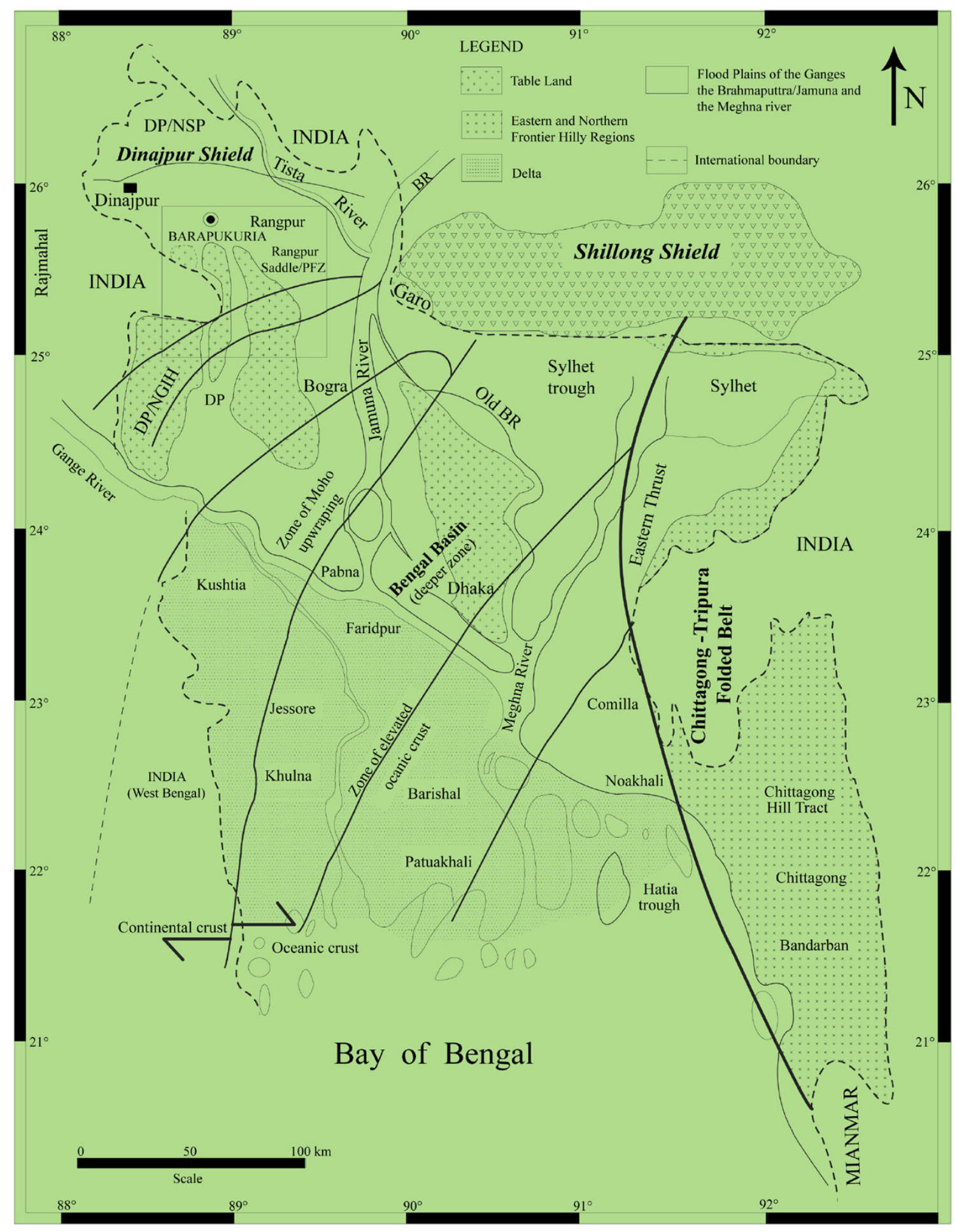

Fig. 2 The geologic and tectonic setting of the BCM Basin, Dinajpur, Bangladesh, where $B R$ Brahmaputtra River, DP Dinajpur Platform, NGIH Nawabganj-Gaibandha Intracratonic High, NSP

covering of Barind clay residuum to its geologically unconformable contact with the groundwater measures. The Dupi Tila formation and Gondwana sandstone, that is known to be hydraulic continuity with the coal seam VI,
North Slope of the Platform, PFZ Platform Flank Zone (modified after Khan 1991; Khan and Chouhan 1996; Islam 2009)

represent a major potential hazard to the mine from water inflow. BCM is an independent Gondwana coal-bearing basin, which is controlled by half-fault Graben and unconformably laid on the denuded Archean Basement 
Fig. 3 Stratigraphic crosssection which shows different water-bearing formations of the BCM Basin, immediately before mining operation started (after Mostofa 2002)

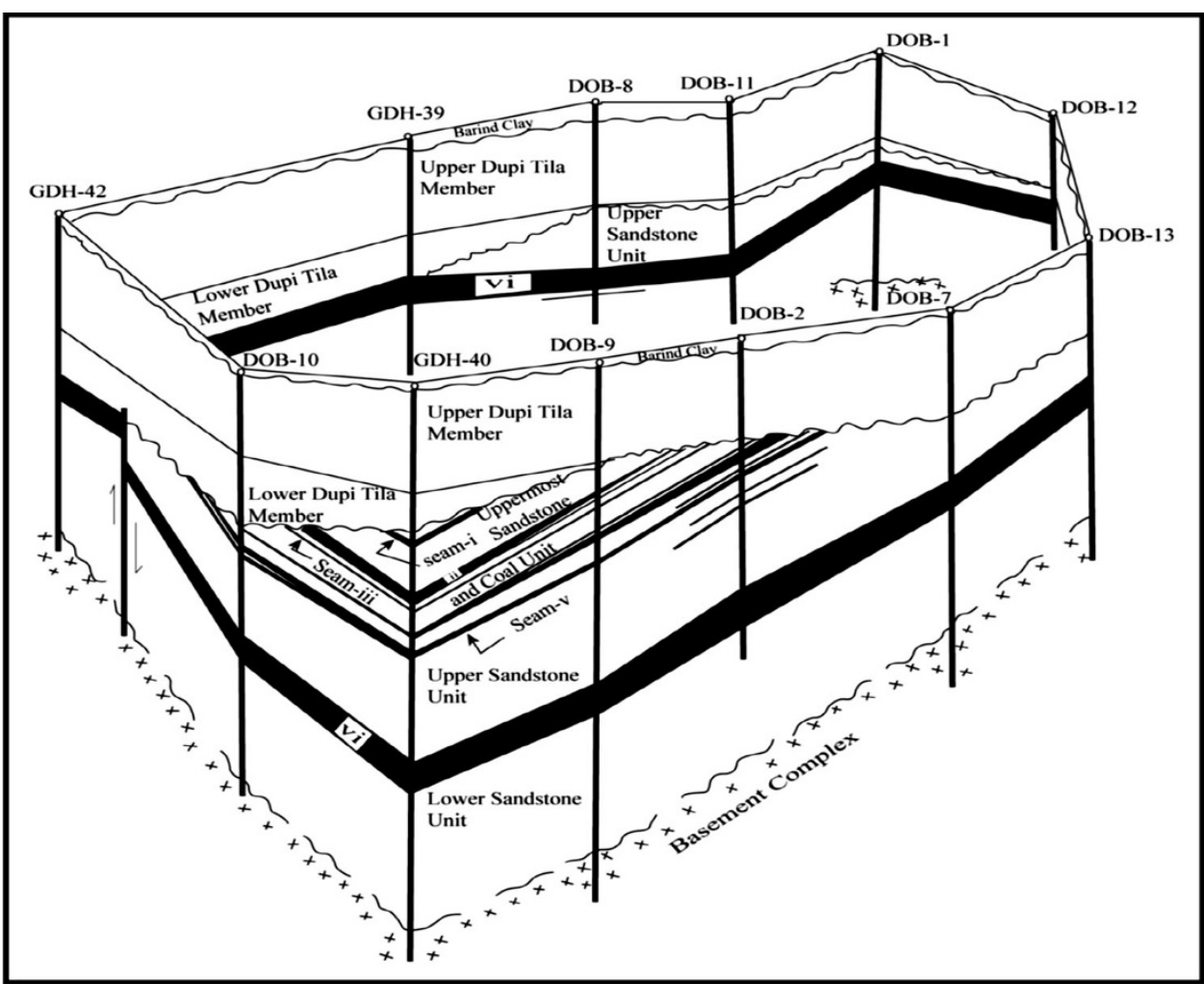

Complex. Drilling data show that the strata can be divided into four units (Fig. 3) such as Basement complex, Gondwana group, Dupi Tila Formation and Barind Residuum Clay (Khan and Chouhan 1996; Alam et al. 2003).

According to the lithological characteristics of such strata obtained during exploration activities, the characteristics of the hydrostratigraphic successions of the study area are shown in Table 1 and Fig. 3. Hydrostratigraphically the Barind Clay Residuum is called an aquiclude, which has an average thickness of $10 \mathrm{~m}$ with an infiltration rate of about $1.5 \mathrm{~mm} /$ day. The upper Dupi Tila (UDT) is an aquifer constituting the major ground water reservoir in the mine area with an average thickness of about $104 \mathrm{~m}$ and depth of the floor varies from 102 to $136 \mathrm{~m}$. The lower Dupi Tila (LDT) is an aquiclude and consisted of grayishwhite weathered residual clay and clayey silt of thickness $80 \mathrm{~m}$ where the depth of the floor varies from 115 to $118 \mathrm{~m}$. The Gondwana sandstones represent completely an aquifer system and the coal seam VI divides this into upper and lower sections. The upper section is the sandstone aquifer of thickness $156 \mathrm{~m}$ located in the center of the basin and consisted of medium- to coarse-grained sandstones and pebbly sandstone interbedded with seam I-V, siltstone and mudstone (Uddin and Islam 1992; CMC 1994). The lower section whose thickness varies from 107 to $244 \mathrm{~m}$ becomes thicker from northwestern and from the southeastern part towards the center of the basin. The basement complex consisted of the upper section and lower section is known as Breccia aquiclude and Basement aquiclude, respectively (Uddin and Islam 1992; Bakr et al. 1996; Uddin 2003).

\section{Sampling and analytical procedure}

Several field investigations have been carried out around the mine area to collect the water samples and evaluate the quality and contamination level of that water bodies around the BCM, while it would provide a better understanding of possible information about the current water state and future environmental implications. However, the 50 (surface SW1-SW25 and groundwater GW26-GW50) samples were collected during middle of summer to the middle of rainy season in 2013 from different location around the BCM. Before collecting the samples dry, clean and sterilized plastic bottles were used to get fresh water for sampling. At first the bottles were rinsed by the pumped water and then collect the water. The collected samples were carefully sealed with proper labeling which were preserved in a refrigerator for laboratory analysis. The electrical conductivity (EC) and $\mathrm{pH}$ were measured in the field using a pH meter (HANNA) and EC meter (HANNA HI 7039P), respectively. The total dissolved solids (TDS) measured simply by EC/TDS meter (Hanna). The major cations, e.g. $\mathrm{Ca}^{2+} ; \mathrm{Mg}^{2+} ; \mathrm{Na}^{+} ; \mathrm{K}^{+} ; \mathrm{Fe}^{\text {total }}$ and anions like $\mathrm{HCO}_{3}{ }^{-}$; $\mathrm{CO}_{3}{ }^{2-} ; \mathrm{Cl}^{-}$and $\mathrm{SO}_{4}{ }^{2-}$ were generated in the laboratory 
Table 1 Hydrostratigraphic succession of the BCM area (after CMC 1994; Howladar 2012)

\begin{tabular}{|c|c|c|c|c|}
\hline Age & Lithologic unit & $\begin{array}{l}\text { Hydro- } \\
\text { stratigraphic } \\
\text { units }\end{array}$ & Lithology & $\begin{array}{l}\text { Average } \\
\text { thickness } \\
(\mathrm{m})\end{array}$ \\
\hline Pliestocene & $\begin{array}{l}\text { Barind Clay } \\
\text { Residium }\end{array}$ & Aquiclude & Clay and sandy clay & 10 \\
\hline \multirow[t]{2}{*}{ Pliocene } & Upper Dupi Tila & Aquifer & Medium sand interbedded with fine sand, pebbly grit and thin clay & 104 \\
\hline & Lower Dupi Tila & Aquiclude & $\begin{array}{l}\text { Weathered residual clay, clay silts, sandstone interbedded with silty mudstone and } \\
\text { coarse grain quartz }\end{array}$ & 80 \\
\hline \multirow[t]{3}{*}{ Permian } & Gondwana & Aquifer & $\begin{array}{l}\text { Medium- to coarse-grained sandstone and Pebbly sandstone, interbedded with } \\
\text { coal seam I-V; also siltstone and mudstone }\end{array}$ & 156 \\
\hline & $\begin{array}{l}\text { 1. Sandstone of } \\
\text { Seam VI Roof }\end{array}$ & Aquifer & $\begin{array}{l}\text { Medium- to coarse-grained sandstone, grit stone, interbedded with thin medium- } \\
\text { to fine-grained sandstone, siltstone and mudstone are sometimes. }\end{array}$ & 140 \\
\hline & $\begin{array}{l}\text { 2. Sandstone of } \\
\text { Seam VI Floor }\end{array}$ & Aquifer & $\begin{array}{l}\text { Fine-grained sandstone, medium- to fine-grained sandstone interbedded with } \\
\text { siltstone, carbonaceous mudstone and } 2 / 3 \text { beds of tuffy siltstone }\end{array}$ & 67 \\
\hline \multirow[t]{2}{*}{ Archean } & $\begin{array}{l}\text { Basement } \\
\text { complex } \\
\text { 1. Upper section }\end{array}$ & $\begin{array}{l}\text { Relatively } \\
\text { aquiclude }\end{array}$ & $\begin{array}{l}\text { Sedimentary, igneous, and metamorphic rocks with sandy and muddy fragments } \\
\text { interbedded with fine-grained sandstone, carbonaceous mudstones and molted } \\
\text { mudstones at bottom }\end{array}$ & 53 \\
\hline & 2. Lower section & Aquiclude & Granodiorite, quartz diorite and diorite gneiss & 31 \\
\hline
\end{tabular}

using the standard methods given by the American Public Health Association (APHA 1995). The results of field and laboratory analysis of various water parameters are shown in Table 2. Indeed, for the sake of research authenticity, the high-purity analytical reagents were used throughout the study, and chemical standards for each element when necessary were prepared separately. Moreover, to ascertain the suitability of surface and groundwater of the area for various purposes such as municipal, agricultural, industrial or drinking quality, the following parameters were also estimated, shown in Table 3. Total hardness (TH) of the groundwater was calculated using the formula given by Sawyer et al. (2003):

$\mathrm{TH}\left(\right.$ as $\left.\mathrm{CaCO}_{3}\right) \mathrm{mg} / \mathrm{L}=\left(\mathrm{Ca}^{2+}+\mathrm{Mg}^{2+}\right) \times 50$

where the concentrations of $\mathrm{Ca}^{2+}$ and $\mathrm{Mg}^{2+}$ are represented in $\mathrm{meq} / \mathrm{L}$.

Residual sodium carbonate (RSC) of the water was computed by the equation (Raghunath 1987):

$\mathrm{RSC}=\left(\mathrm{CO}_{3}+\mathrm{HCO}_{3}\right)-\left(\mathrm{Ca}^{2+}+\mathrm{Mg}^{2+}\right)$

where all concentrations are represented in meq/L.

Permeability index (PI) was estimated using the formula developed by Doneen (1964):

$\mathrm{PI}=\frac{\mathrm{Na}+\sqrt{\mathrm{HCO}_{3}}}{\mathrm{Ca}+\mathrm{Mg}+\mathrm{Na}} \times 100$

where all concentrations are represented in meq/L.

The Sodium adsorption ratio (SAR) was calculated by Richards (1954) equation:

$\mathrm{SAR}=\frac{\mathrm{Na}}{\sqrt{(\mathrm{Ca}+\mathrm{Mg}) / 2}}$ where the concentrations are reported in meq/L.

Sodium percentage $(\mathrm{Na} \%)$ was calculated by the following equation (Todd 1980):

$\mathrm{Na} \%=\frac{(\mathrm{Na}+\mathrm{K}) \times 100}{\mathrm{Ca}+\mathrm{Na}+\mathrm{Mg}+\mathrm{K}}$

where all the ions are expressed in meq/L.

Magnesium hazard $(\mathrm{MH})$ value was determined by the following formula proposed by Szabolcs and Darab (1964) for irrigation water use:

$\mathrm{MH}=\frac{\mathrm{Mg}}{\mathrm{Ca}+\mathrm{Mg}} \times 100$

where all the ions are expressed in meq/L.

\section{Results and discussions}

Chemistry of surface and groundwater around the BCM Industry

The water samples around the BCM were collected from different locations and analyzed them in laboratory for understanding their present state and future suitability. The results of chemical analysis show that a series of disparity exists in the parameters of water. The data obtained by chemical analyses were evaluated in terms of suitability as shown in Tables 2 and 3, and are represented in bar diagrams in Figs. 4 and 5. In general, the pH of surface and groundwater samples ranges between 6.3 and 8.31, which is almost belonging to the average standard ranges $6.5-8.5$ of WHO (2011). The EC, TDS and TH concentrations are within or 
Table 2 The chemistry of surface and groundwater around the BCM area

\begin{tabular}{|c|c|c|c|c|c|c|c|c|c|c|c|c|}
\hline $\begin{array}{l}\text { Sample } \\
\text { no. }\end{array}$ & $\mathrm{pH}$ & $\begin{array}{l}\mathrm{EC}(\mu \mathrm{s} / \\
\mathrm{cm})\end{array}$ & $\begin{array}{l}\text { TDS (mg/ } \\
\mathrm{L})\end{array}$ & $\begin{array}{l}\mathrm{Na}^{+}(\mathrm{mg} / \\
\mathrm{L})\end{array}$ & $\begin{array}{l}\mathrm{K}^{+}(\mathrm{mg} / \\
\mathrm{L})\end{array}$ & $\begin{array}{l}\mathrm{Ca}^{2+}(\mathrm{mg} / \\
\mathrm{L})\end{array}$ & $\begin{array}{l}\mathrm{Mg}^{2+} \\
(\mathrm{mg} / \mathrm{L})\end{array}$ & $\begin{array}{l}\mathrm{Fe}^{\text {total }} \\
(\mathrm{mg} / \mathrm{L})\end{array}$ & $\begin{array}{l}\mathrm{Cl}^{-}(\mathrm{mg} / \\
\mathrm{L})\end{array}$ & $\begin{array}{l}\mathrm{HCO}_{3}^{-} \\
(\mathrm{mg} / \mathrm{L})\end{array}$ & $\begin{array}{l}\mathrm{CO}_{3}^{2-} \\
(\mathrm{mg} / \mathrm{L})\end{array}$ & $\begin{array}{l}\mathrm{SO}_{4}{ }^{2-} \\
(\mathrm{mg} / \mathrm{L})\end{array}$ \\
\hline SW 1 & 7.84 & 497 & 318.08 & 19.32 & 7.43 & 50 & 18 & 1.20 & 6.82 & 210.45 & 5 & 15 \\
\hline SW 2 & 7.93 & 366 & 234.24 & 20.19 & 6.93 & 62 & 15 & 1.10 & 6.18 & 200.20 & 7 & 12 \\
\hline SW 3 & 7.82 & 220 & 140.80 & 17.32 & 5.20 & 55 & 12 & 1.21 & 7.28 & 205.42 & 6.20 & 13 \\
\hline SW 4 & 7.61 & 205 & 131.20 & 16.20 & 7.15 & 51.12 & 11 & 1.30 & 8.17 & 205.89 & 8.57 & 12.15 \\
\hline SW 5 & 7.52 & 190 & 121.60 & 12.20 & 7.16 & 53.32 & 18.82 & 1.50 & 7.37 & 208 & 9 & 11 \\
\hline SW 6 & 7.62 & 192 & 122.88 & 17.25 & 6.60 & 57 & 19 & 1.40 & 8.92 & 215.52 & 8.85 & 13.32 \\
\hline SW 7 & 7.25 & 215 & 137.60 & 18.72 & 6 & 49.12 & 20 & 1.32 & 7.20 & 220.45 & 10.12 & 12.25 \\
\hline SW 8 & 7.81 & 273 & 174.72 & 21.32 & 8.82 & 52.25 & 23 & 1.12 & 8.75 & 221.32 & 10.15 & 12.31 \\
\hline SW 9 & 6.91 & 512 & 327.68 & 23.57 & 12.75 & 58.75 & 21 & 1.42 & 9.25 & 211.12 & 9.25 & 13.31 \\
\hline SW 10 & 7.12 & 550 & 352 & 24.35 & 13.12 & 62.20 & 25 & 0.90 & 11.31 & 202.32 & 6 & 20 \\
\hline SW 11 & 8.21 & 230 & 147.20 & 25.52 & 7.25 & 71.25 & 32.09 & 1.50 & 20.46 & 190.52 & 11.25 & 17.79 \\
\hline SW 12 & 7.35 & 160 & 102.40 & 16.25 & 13 & 66.12 & 19.90 & 0.80 & 12.57 & 219.52 & 9.90 & 21 \\
\hline SW 13 & 8.31 & 620 & 396.80 & 25.76 & 9.75 & 64.52 & 18.75 & 0.75 & 11.94 & 225.32 & 7.70 & 9 \\
\hline SW 14 & 8.12 & 226 & 144.64 & 11.12 & 10.12 & 61.72 & 12.12 & 1.11 & 13.73 & 218.79 & 2.50 & 19 \\
\hline SW 15 & 7.98 & 385 & 246.40 & 28.75 & 9.18 & 52.12 & 13.30 & 1.19 & 15.57 & 213.57 & 11.10 & 12.50 \\
\hline SW 16 & 7.39 & 180 & 115.20 & 15.52 & 13.25 & 61.75 & 18.19 & 1.05 & 16.12 & 201.12 & 3.39 & 13.13 \\
\hline SW 17 & 7.55 & 611 & 391.04 & 31.12 & 6.15 & 68.77 & 25.75 & 0.85 & 13.75 & 203.31 & 10 & 9.10 \\
\hline SW 18 & 7.23 & 515 & 329.60 & 27.72 & 7.70 & 65.50 & 13.32 & 1.50 & 12.15 & 209.92 & 7.50 & 18 \\
\hline SW 19 & 6.95 & 478 & 305.92 & 32.31 & 12.25 & 60.20 & 14.41 & 1.18 & 19.23 & 211.72 & 7.79 & 14 \\
\hline SW 20 & 7.17 & 626 & 400.64 & 26.35 & 11.12 & 57.12 & 25.99 & 1.27 & 12.99 & 222.12 & 7.20 & 11.20 \\
\hline SW 21 & 7.30 & 242 & 154.88 & 18.75 & 10.72 & 58.15 & 20.19 & 1.37 & 11.20 & 217.31 & 6.19 & 14.31 \\
\hline SW 22 & 7.52 & 185 & 118.40 & 14.39 & 11.31 & 51.72 & 21.72 & 0.95 & 7.95 & 211.75 & 7.22 & 12.35 \\
\hline SW 23 & 7.63 & 420 & 268.80 & 13.73 & 15.50 & 60.75 & 13.50 & 1.27 & 17.72 & 225.72 & 7.95 & 16.19 \\
\hline SW 24 & 7.68 & 313 & 200.32 & 13.57 & 13.35 & 52.72 & 11.72 & 1.17 & 19.33 & 213.99 & 8.20 & 13.35 \\
\hline SW 25 & 7.81 & 195 & 124.80 & 21.71 & 6.25 & 75.50 & 16.19 & 1.25 & 8.95 & 216.12 & 4.40 & 11.72 \\
\hline Gw 26 & 7.89 & 622 & 398.08 & 23.57 & 11.20 & 78.20 & 15.57 & 1.30 & 12.25 & 216.52 & 8.25 & 12.71 \\
\hline Gw 27 & 7.85 & 209 & 133.76 & 18.12 & 12.15 & 77.17 & 18.99 & 1.45 & 13.77 & 216.99 & 10.10 & 14.32 \\
\hline Gw 28 & 6.98 & 245 & 156.80 & 17.57 & 13.31 & 71.95 & 22.51 & 1.16 & 11.92 & 213.32 & 9.19 & 16.75 \\
\hline Gw 29 & 7.97 & 150 & 96 & 21.19 & 9.19 & 70.70 & 16.95 & 1.22 & 19.78 & 218.75 & 5.50 & 12.12 \\
\hline Gw 30 & 7.83 & 280 & 179.20 & 22.57 & 8.75 & 69.52 & 12.97 & 0.99 & 13.58 & 211.92 & 7.23 & 13.19 \\
\hline Gw 31 & 7.75 & 295 & 188.80 & 33.33 & 12.29 & 54.20 & 19.20 & 1.42 & 11.10 & 205.71 & 7.71 & 12.20 \\
\hline Gw 32 & 8.12 & 527 & 337.28 & 34.52 & 11.95 & 72.25 & 15.92 & 1.14 & 6.75 & 195.52 & 7.29 & 15.50 \\
\hline Gw 33 & 7.25 & 540 & 345.60 & 25.75 & 14.72 & 73.50 & 17.79 & 1.31 & 6.19 & 185.19 & 3.25 & 15.79 \\
\hline Gw 34 & 8.11 & 549 & 351.36 & 29.32 & 14.56 & 63.32 & 12.11 & 1.13 & 7.72 & 219.12 & 8.12 & 15.12 \\
\hline Gw 35 & 7.22 & 560 & 358.40 & 30.35 & 11.19 & 64.25 & 21.32 & 1.50 & 11.79 & 201.32 & 8.50 & 12.79 \\
\hline Gw 36 & 7.29 & 428 & 273.92 & 16.53 & 15.94 & 62.72 & 13.55 & 1.40 & 18.75 & 207.75 & 7.72 & 17.71 \\
\hline Gw 37 & 7.56 & 477 & 305.28 & 27.72 & 13.23 & 55.71 & 22.58 & 1.25 & 13.72 & 200.70 & 7.30 & 14.31 \\
\hline Gw 38 & 7.28 & 424 & 271.36 & 35.50 & 11.78 & 63.95 & 16.50 & 1.19 & 12.95 & 206.99 & 5.52 & 12.57 \\
\hline Gw 39 & 6.99 & 339 & 216.96 & 31.90 & 7.12 & 52.99 & 21.78 & 1.33 & 14.42 & 203.32 & 4.25 & 14.95 \\
\hline Gw 40 & 7.40 & 479 & 306.56 & 32.55 & 7.50 & 76.20 & 14.40 & 1.10 & 17.95 & 210.50 & 5.15 & 11.25 \\
\hline Gw 41 & 6.30 & 192 & 122.88 & 8.30 & 8.19 & 10.30 & 8.30 & 1.10 & 15.20 & 201.20 & 8.20 & 11.12 \\
\hline Gw 42 & 7.40 & 142 & 90.88 & 5.10 & 11.21 & 6.10 & 5.60 & 1.12 & 8.70 & 212.73 & 7.50 & 12.71 \\
\hline Gw 43 & 7.40 & 69 & 44.16 & 4.2 & 8.79 & 7.60 & 6.20 & 1.20 & 9.20 & 190.79 & 3.20 & 21.21 \\
\hline Gw 44 & 6.80 & 72 & 46.08 & 3.9 & 13.22 & 8.10 & 5.30 & 1.00 & 7.30 & 185.69 & 6.50 & 20.10 \\
\hline Gw 45 & 6.90 & 117 & 74.88 & 6.2 & 16.55 & 11.20 & 9.50 & 0.95 & 12.80 & 205.81 & 7.20 & 13.39 \\
\hline Gw 46 & 7.20 & 94 & 60.16 & 4.3 & 25.82 & 6.40 & 5.40 & 0.80 & 6.90 & 209.91 & 8.90 & 18.76 \\
\hline Gw 47 & 6.90 & 164 & 104.96 & 12.60 & 18.75 & 13.60 & 10.50 & 1.31 & 16.10 & 215.72 & 6.10 & 15.12 \\
\hline Gw 48 & 7.10 & 148 & 94.72 & 11.90 & 15.50 & 14.30 & 11.20 & 1.02 & 18.30 & 207.72 & 5.50 & 9.19 \\
\hline Gw 49 & 7.20 & 125 & 80 & 6.70 & 12.21 & 11.60 & 9.30 & 1.13 & 12.60 & 195.59 & 9.10 & 17.12 \\
\hline
\end{tabular}


Table 2 continued

\begin{tabular}{|c|c|c|c|c|c|c|c|c|c|c|c|c|}
\hline $\begin{array}{l}\text { Sample } \\
\text { no. }\end{array}$ & $\mathrm{pH}$ & $\begin{array}{l}\mathrm{EC}(\mu \mathrm{s} / \\
\mathrm{cm})\end{array}$ & $\begin{array}{l}\text { TDS (mg/ } \\
\text { L) }\end{array}$ & $\begin{array}{l}\mathrm{Na}^{+}(\mathrm{mg} / \\
\mathrm{L})\end{array}$ & $\begin{array}{l}\mathrm{K}^{+}(\mathrm{mg} / \\
\mathrm{L})\end{array}$ & $\begin{array}{l}\mathrm{Ca}^{2+}(\mathrm{mg} / \\
\mathrm{L})\end{array}$ & $\begin{array}{l}\mathrm{Mg}^{2+} \\
(\mathrm{mg} / \mathrm{L})\end{array}$ & $\begin{array}{l}\mathrm{Fe}^{\text {total }} \\
(\mathrm{mg} / \mathrm{L})\end{array}$ & $\begin{array}{l}\mathrm{Cl}^{-}(\mathrm{mg} / \\
\mathrm{L})\end{array}$ & $\begin{array}{l}\mathrm{HCO}_{3}^{-} \\
(\mathrm{mg} / \mathrm{L})\end{array}$ & $\begin{array}{l}\mathrm{CO}_{3}{ }^{2-} \\
(\mathrm{mg} / \mathrm{L})\end{array}$ & $\begin{array}{l}\mathrm{SO}_{4}{ }^{2-} \\
(\mathrm{mg} / \mathrm{L})\end{array}$ \\
\hline Gw 50 & 7.40 & 158 & 101.12 & 7.30 & 11.75 & 13.40 & 9.80 & 1.40 & 12.40 & 197.91 & 10.10 & 14.15 \\
\hline WHO & $6.5-8.5$ & 250 & 500 & 200 & a & 70 & 150 & 0.30 & 250 & 100 & a & 200 \\
\hline EOS & $6.5-8.5$ & 250 & 500 & a & a & $\mathrm{a}$ & 50 & 1.00 & 250 & a & $\mathrm{a}$ & $\mathrm{a}$ \\
\hline
\end{tabular}

SW Surface water samples, GW ground water samples

${ }^{\text {a }}$ Not mentioned

below the desirable limit of 69-670 $\mu \mathrm{s} / \mathrm{cm}, 44.16-400.64$ and $38.5-273.67 \mathrm{mg} / \mathrm{L}$, respectively. The concentration of cations such as $\mathrm{Ca}^{2+}, \mathrm{Mg}^{2+}, \mathrm{Na}^{+}, \mathrm{K}^{+}$and $\mathrm{Fe}^{\text {total }}$ ranges from 49.12 to $75.5 \mathrm{mg} / \mathrm{L}, 11$ to $32.09 \mathrm{mg} / \mathrm{L}, 11.12$ to $32.31 \mathrm{mg} / \mathrm{L}$, 5.2 to $13.35 \mathrm{mg} / \mathrm{L}$ and 0.75 to $1.42 \mathrm{mg} / \mathrm{L}$ for surface water, and from 6.1 to $78.2 \mathrm{mg} / \mathrm{L}, 5.5$ to $22.58 \mathrm{mg} / \mathrm{L}, 3.9$ to $35.5 \mathrm{mg} / \mathrm{L}, 7.12$ to $25.82 \mathrm{mg} / \mathrm{L}$ and 0.8 to $1.45 \mathrm{mg} / \mathrm{L}$ for ground waters, respectively. Besides the concentration of anions resembling $\mathrm{HCO}_{3}{ }^{-}, \mathrm{Cl}^{-}, \mathrm{SO}_{4}{ }^{2-}$ and $\mathrm{CO}_{3}{ }^{2-}$ absorption in the surface water ranges from 190.52 to $225.72 \mathrm{mg} / \mathrm{L}$, 6.18 to $20.46 \mathrm{mg} / \mathrm{L}, 9$ to $20 \mathrm{mg} / \mathrm{L}, 2.5$ to $11.25 \mathrm{mg} / \mathrm{L}$ and in ground water ranges from 185.19 to $219.12 \mathrm{mg} / \mathrm{L}, 6.19$ to $19.78 \mathrm{mg} / \mathrm{L}, 9.19$ to $21.21 \mathrm{mg} / \mathrm{L}, 3.2$ to $10.1 \mathrm{mg} / \mathrm{L}$, respectively. Thus, the abundance of the major ions is as follows: $\mathrm{Ca}^{2+}>\mathrm{Na}^{+}>\mathrm{Mg}^{2+}>\mathrm{K}^{+}>\mathrm{Fe}^{\text {total }}=\mathrm{HCO}_{3}{ }^{-}>\mathrm{SO}_{4}{ }^{2-}$ $>\mathrm{Cl}^{-}>\mathrm{CO}_{3}{ }^{2-}$ which is belonging to suggested values by WHO (2011). However, among the cations, $\mathrm{Ca}^{2+}$ is the major and $\mathrm{Fe}^{\text {total }}$ is the lowest constituent whereas the $\mathrm{HCO}_{3}{ }^{-}$and $\mathrm{CO}_{3}{ }^{2-}$ are the most dominant and lowest ingredients in the anions (Table 2; Fig. 4a, b). The $\mathrm{Na}^{+}, \mathrm{Mg}^{2+}, \mathrm{K}^{+}, \mathrm{SO}_{4}{ }^{2-}$ and $\mathrm{Cl}^{-}$are shown as the intermediate level of concentration in the cations and anions of the surface and ground water samples in the area, respectively. Moreover, considering the $\mathrm{pH}$ values from 6.3 to 8.31 with an average value of 7.3 and also concentration of other physico-chemical parameters, this research implied that the water in the study area is slightly alkaline in nature and slightly varies in chemical composition of the samples in both cases. Moreover, the Schoeller (1965) diagram is applied for showing the proportional alterations in the concentrations as well as proportion of water eminence parameters for dissimilar samples. The dissimilar water excellence variables are intrigued along with their concentrations shown in Fig. 4a, b. Results stipulate that lines of similar slope connecting concentrations of different parameters are indicative of water from an analogous source. Most of the water types are of high $\mathrm{HCO}_{3}{ }^{-}$content with almost the similar higher concentration of $\mathrm{Ca}^{2+}, \mathrm{Mg}^{2+}$ and $\mathrm{Na}^{+}$.

Graphical presentation of hydrochemical character of water samples

The geochemical behavior and hydrochemical types of surface and subsurface water in any area can be understood by representing the Piper's Trilinear and Expanded Durov diagram (Walton 1970; Ophori and Toth 1989; Hounslow 1995; Arumugam and Elangovan 2009; Bhardwaj and Singh 2011; Hossain et al. 2010; Bahar and Reza 2010; Yangui et al. 2012 and so many) while these methods are more definite and reliable than other possible plotting methods. The Trilinear diagram developed by Piper (1953) is one of the most important and useful diagram for representing and comparing water quality analysis. It is an effective tool in separating hydrochemical analysis data for critical studies with respect to the sources of dissolved constituents (major cations: $\mathrm{Ca}^{2+}, \mathrm{Mg}^{2+}, \mathrm{Na}^{+}, \mathrm{K}^{+}$, and major anions: $\mathrm{HCO}_{3}{ }^{-}, \mathrm{Cl}^{-}, \mathrm{SO}_{4}{ }^{2-}$ and $\mathrm{CO}_{3}{ }^{-}$) in the waters, modifications in the character of water as it passes through an area and related geochemical problems. Major cations and anions are plotted in the two base triangles of the diagram as cation and anion percentages of milligrams per liter (mg/L). The central plotting field (diamond shape) of the trilinear diagram indicates the classification of the water. Here, alkali cations $\left(\mathrm{Na}^{+}\right.$and $\left.\mathrm{K}^{+}\right)$are called primary constituents and the alkaline earth cations $\mathrm{CCa}^{2+}$ and $\mathrm{Mg}^{2+}$ ) are called secondary constituents. The strong acid anions $\left(\mathrm{SO}_{4}{ }^{2-}\right.$ and $\left.\mathrm{Cl}^{-}\right)$are treated as saline constituents; and $\mathrm{CO}_{3}{ }^{2-}$ and $\mathrm{HCO}_{3}{ }^{-}$are treated as a weak acid. In fact, the mutual balancing of these cations and anions determines the chemical character of the water. All of the samples' weak acids exceed strong acids and finally the majority of the samples indicate secondary constituents exceed primary constituents. It may be concluded that the water samples of the study area are the dominance of alkaline earths $\left(\mathrm{Ca}^{2+}\right.$ and $\left.\mathrm{Mg}^{2+}\right)$ and weak acids $\left(\mathrm{HCO}_{3}{ }^{-}\right)$. Besides, Expanded Durov diagram is the other important graphical forms, developed by Burden and Mazloum (1965), Lloyd (1965) provides a distinct classification of the combination of major cations and anions. It is based on the percentage of major ions expressed as $\mathrm{mg} / \mathrm{L}$, and the cations and anions together form a total $100 \%$. The expanded Durov diagram provides a better display of hydrochemical types and some processes (Lloyd and Heathcote 1985). From the above discussion, it can be concluded that the waters of the study area are classified as calcium-bicarbonate and magnesium-bicarbonate types which support that shallow recently recharged water like 
Table 3 The calculated total hardness (TH), sodium absorption ratio (SAR), sodium percentage (Na\%), residual sodium carbonate (RSC), permeability index (PI) and magnesium hardness $(\mathrm{MH})$

\begin{tabular}{|c|c|c|c|c|c|c|}
\hline Sample no. & TH (meq/L) & SAR (meq/L) & $\mathrm{Na} \%$ & RSC (meq/L) & PI (meq/L) & MH (meq/L) \\
\hline SW 1 & 200 & 0.59397 & 20.48524 & -0.38333 & 55.73177 & 37.50 \\
\hline SW 2 & 217.50 & 0.595222 & 19.52668 & -0.8347 & 51.44483 & 28.73563 \\
\hline SW 3 & 187.50 & 0.549945 & 19.11788 & -0.17579 & 57.47512 & 26.66667 \\
\hline SW 4 & 173.6333 & 0.534528 & 20.35804 & 0.188246 & 60.84566 & 26.39662 \\
\hline SW 5 & 211.7167 & 0.364548 & 14.42952 & -0.5245 & 49.88719 & 37.03849 \\
\hline SW 6 & 221.6667 & 0.503745 & 17.17365 & -0.60522 & 50.73295 & 35.71429 \\
\hline SW 7 & 206.1333 & 0.566897 & 19.01136 & -0.1714 & 54.99654 & 40.42691 \\
\hline SW 8 & 226.4583 & 0.615978 & 20.2931 & -0.56264 & 51.9002 & 42.31831 \\
\hline SW 9 & 234.375 & 0.669385 & 22.38218 & -0.91818 & 50.50791 & 37.33333 \\
\hline SW 10 & 259.6667 & 0.656996 & 21.17506 & -1.67661 & 46.06317 & 40.11553 \\
\hline SW 11 & 311.8333 & 0.628335 & 17.19916 & -2.73839 & 39.16083 & 42.87814 \\
\hline SW 12 & 248.2167 & 0.448446 & 17.31883 & -1.03564 & 45.91094 & 33.40496 \\
\hline SW 13 & 239.425 & 0.723824 & 22.24568 & -0.83806 & 51.48377 & 32.63026 \\
\hline SW 14 & 204.80 & 0.337841 & 15.35381 & -0.42595 & 51.91295 & 24.6582 \\
\hline SW 15 & 185.7167 & 0.917243 & 28.56664 & 0.156814 & 62.87119 & 29.83936 \\
\hline SW 16 & 230.1667 & 0.444777 & 18.05895 & -1.19328 & 47.18654 & 32.92904 \\
\hline SW 17 & 279.2167 & 0.809732 & 21.29276 & -1.91805 & 45.81963 & 38.42595 \\
\hline SW 18 & 219.25 & 0.813946 & 24.23527 & -0.69369 & 54.74375 & 25.31357 \\
\hline SW 19 & 210.5417 & 0.968144 & 28.98764 & -0.48035 & 58.19123 & 28.51771 \\
\hline SW 20 & 251.0917 & 0.722997 & 22.17366 & -1.14052 & 49.51571 & 43.12834 \\
\hline SW 21 & 229.50 & 0.538124 & 19.19141 & -0.82121 & 50.00104 & 36.65577 \\
\hline SW 22 & 219.80 & 0.422006 & 17.23856 & -0.68402 & 49.56133 & 41.17379 \\
\hline SW 23 & 208.125 & 0.413791 & 19.28278 & -0.19717 & 52.95941 & 27.02703 \\
\hline SW 24 & 180.6333 & 0.438988 & 20.51294 & 0.168699 & 58.60504 & 27.03451 \\
\hline SW 25 & 256.2083 & 0.589706 & 17.72816 & -1.43455 & 46.57463 & 26.32948 \\
\hline GW 26 & 260.375 & 0.635085 & 20.12378 & -1.38299 & 46.67305 & 24.91599 \\
\hline GW 27 & 272.05 & 0.477646 & 16.80892 & -1.54712 & 42.92757 & 29.08473 \\
\hline GW 28 & 273.6667 & 0.461778 & 16.80004 & -1.66995 & 42.22942 & 34.27223 \\
\hline GW 29 & 247.375 & 0.585767 & 18.95251 & -1.1781 & 47.9654 & 28.54977 \\
\hline GW 30 & 227.8417 & 0.65011 & 20.92259 & -0.84173 & 51.37463 & 23.71896 \\
\hline GW 31 & 215.50 & 0.987152 & 29.04484 & -0.6807 & 57.04874 & 37.12297 \\
\hline GW 32 & 246.9583 & 0.955061 & 26.78862 & -1.49092 & 51.10514 & 26.86013 \\
\hline GW 33 & 257.875 & 0.69718 & 22.49607 & -2.01327 & 45.59375 & 28.74455 \\
\hline GW 34 & 208.7583 & 0.882296 & 28.30218 & -0.31237 & 58.16704 & 24.17069 \\
\hline GW 35 & 249.4583 & 0.835472 & 24.35677 & -1.40551 & 49.71277 & 35.61049 \\
\hline GW 36 & 213.2583 & 0.492144 & 20.90676 & -0.6021 & 51.44925 & 26.47415 \\
\hline GW 37 & 233.3583 & 0.788958 & 24.86388 & -1.13367 & 51.4118 & 40.31711 \\
\hline GW 38 & 228.625 & 1.020795 & 28.75539 & -0.99522 & 55.35605 & 30.07108 \\
\hline GW 39 & 223.225 & 0.928307 & 26.01119 & -0.98972 & 54.90323 & 40.65405 \\
\hline GW 40 & 250.50 & 0.894168 & 24.29194 & -1.38751 & 50.93766 & 23.9521 \\
\hline GW 41 & 60.33333 & 0.464592 & 32.11578 & 2.365027 & 138.8809 & 57.32044 \\
\hline GW 42 & 38.58333 & 0.356979 & 39.75316 & 2.96571 & 210.3059 & 60.47516 \\
\hline GW 43 & 44.83333 & 0.272722 & 31.272 & 2.337705 & 180.7825 & 57.62082 \\
\hline GW 44 & 42.33333 & 0.260613 & 37.52488 & 2.414098 & 188.3723 & 52.16535 \\
\hline GW 45 & 67.58333 & 0.327902 & 33.92292 & 2.262268 & 129.9254 & 58.56967 \\
\hline GW 46 & 38.50 & 0.301308 & 52.44001 & 2.967814 & 213.3837 & 58.44156 \\
\hline GW 47 & 77.75 & 0.621287 & 39.81256 & 2.184727 & 115.4806 & 56.2701 \\
\hline
\end{tabular}


Table 3 continued

\begin{tabular}{lllllll}
\hline Sample no. & TH $(\mathrm{meq} / \mathrm{L})$ & SAR $(\mathrm{meq} / \mathrm{L})$ & Na\% & RSC $(\mathrm{meq} / \mathrm{L})$ & PI $(\mathrm{meq} / \mathrm{L})$ & MH $(\mathrm{meq} / \mathrm{L})$ \\
\hline GW 48 & 82.41667 & 0.569917 & 35.69137 & 1.940246 & 109.0961 & 56.62285 \\
GW 49 & 67.75 & 0.35391 & 30.84552 & 2.154727 & 126.4617 & 57.19557 \\
GW 50 & 74.33333 & 0.368132 & 29.38591 & 2.094426 & 117.4364 & 54.93274 \\
\hline
\end{tabular}

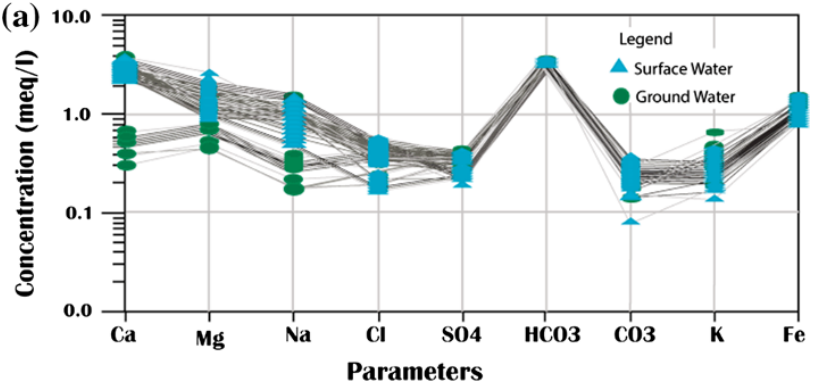

(b)

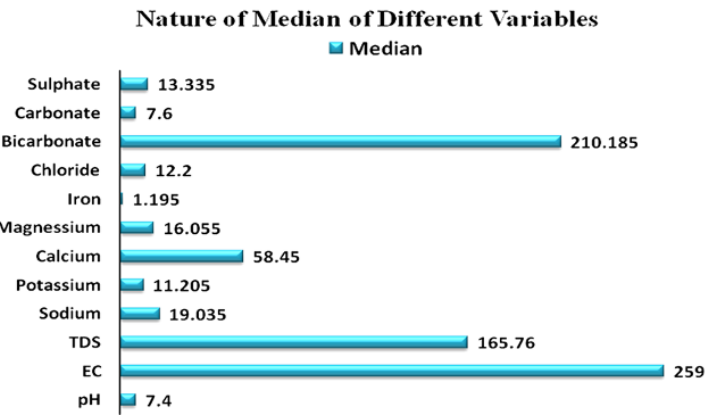

Fig. 4 a Schoeller plot (1965) for ground and surface water parameters around the mining industrial area. b The median values show the abundance of different ions of water around the mining industry

other flood plain areas of Bangladesh are of $\mathrm{Ca}-\mathrm{HCO}_{3}$ type (Ahmed et al. 2000; Karim and Ahmed (unpublished) 2002; Hossain et al. 2010; Davis and Exley 1992; Hossain et al. 2010).

The statistically analyzed different water parameters with their correlation matrix

The assessment of the classes of the surface and ground water is crucial while they are used for drinking, domestic, agricultural and industrial purposes which can be done by various processes. However, in the present research, the different investigative components of water are furthermore justified with adopting various statistical parameters such as the minimum concentration, the maximum concentration, the mean, the standard deviation and the coefficient of variation of each parameter shown in Table 4. On the other hand, combining the physico-chemical and statistical parameters of the water, the evaluated recapitulate categories of water are shown in Table 8. From Tables 4 and 7, it can be noted in a sentence that the qualitative parameters of water are good to excellent in condition for almost all purposes around the mining area. Indeed the statistical analysis of different parameters show the very acceptable limit of water parameters such as the ranges of $\mathrm{pH}$ values is 6.30-8.31 with mean, standard deviation and variation of coefficient value of $7.48,0.422$ and 0.056 , respectively. The TDS ranges from 44.160 to $400.640 \mathrm{mg} / \mathrm{L}$ with a mean value of $204.941 \mathrm{mg} / \mathrm{L}$, where the value of standard deviation is 109.637 . In the case of other parameters such as $\mathrm{Na}, \mathrm{K}, \mathrm{Ca}, \mathrm{Mg}, \mathrm{Fe}$ and so on; show more or less the analogous nature which might be the indicator of having tightly grouped, precise homogeneous good-quality water resources in the area. These results are also much corelatable with different water classifications which show that the water in the area is good-excellent for different usages.

\section{Correlation coefficient matrix $(r)$}

The correlation coefficient is one of the important tests for understanding the possible connections between two independent parameters. For example, it is useful if a linear equation is compared to experimental points.

The following equation (MacMillan et al. 2007) is used:

$r=\frac{\sum\left(X_{i}-X_{\text {mean }}\right)\left(Y i-Y_{\text {mean }}\right)}{\sqrt{\sum\left(X_{i}-X_{\text {mean }}\right)^{2}} \sqrt{\sum\left(Y_{i}-Y_{\text {mean }}\right)^{2}}}$

The correlation coefficient is a frequently employed way to ascertain the connection between two variables. It is merely a measure to demonstrate how well one variable predicts the other (Bahar and Reza 2010). For these purposes, the correlation coefficient has been estimated using quality parameters of ground and surface water samples around the BCM industry shown in Tables 3 and 5. The correlation coefficient is denoted by $r$ and the range of $r$ is varying from -1 to +1 . If the $r$ value is close to -1 then the relationship is considered as anti-correlated or has a negative slope. Besides, the value is close to +1 then the association is considered to be correlated, or to have a positive slope. As the $r$ value deviates from either of these values and approaches zero, the points are considered to become less correlated and eventually are uncorrelated (MacMillan et al. 2007; Srivastava and 
Fig. 5 The Piper diagram (a) and Expanded Durov diagram (b) graphical plotting of ground and surface water around the BCM industry

\section{Piper Diagram}

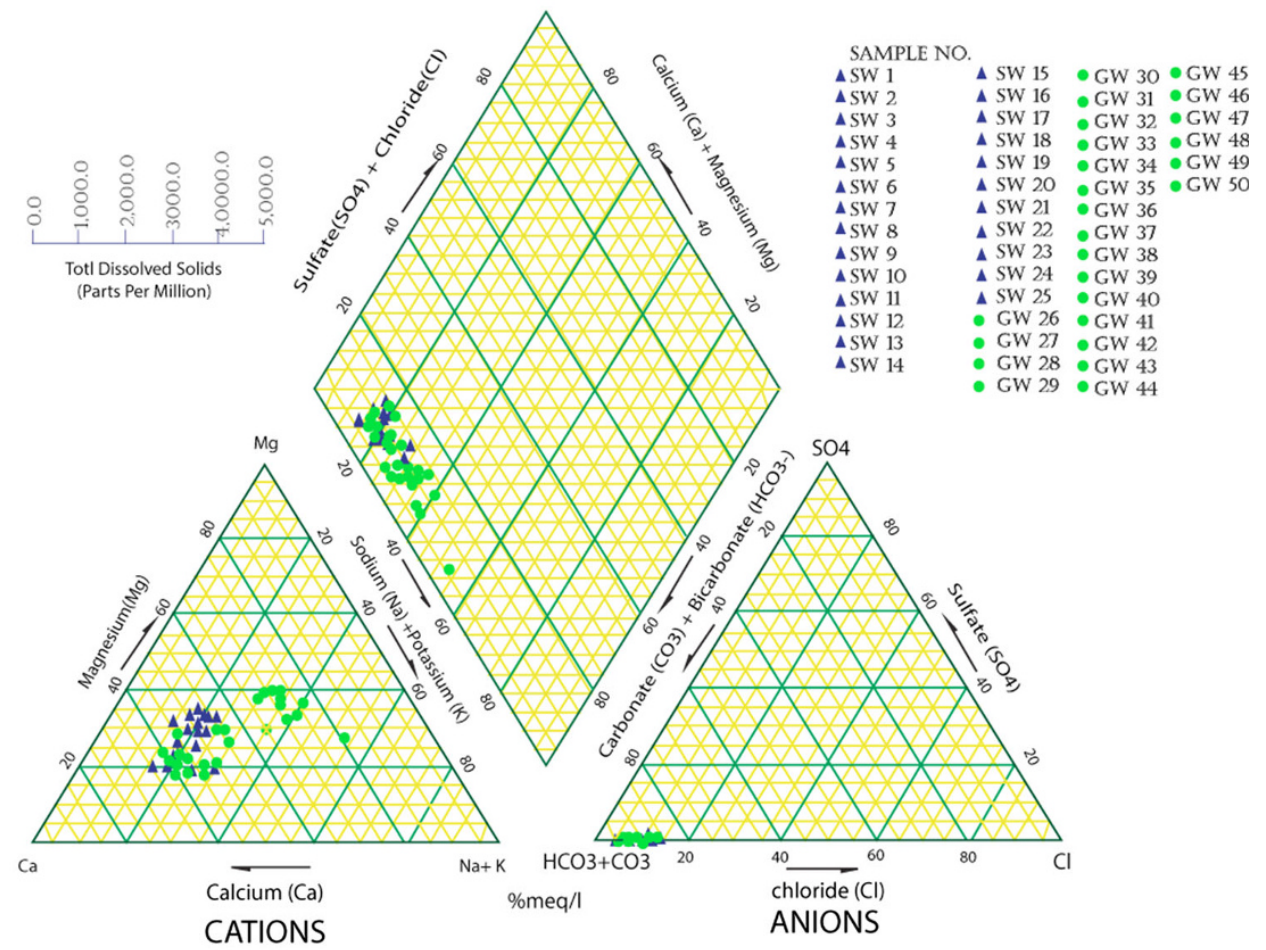

(a) Piper Diagram

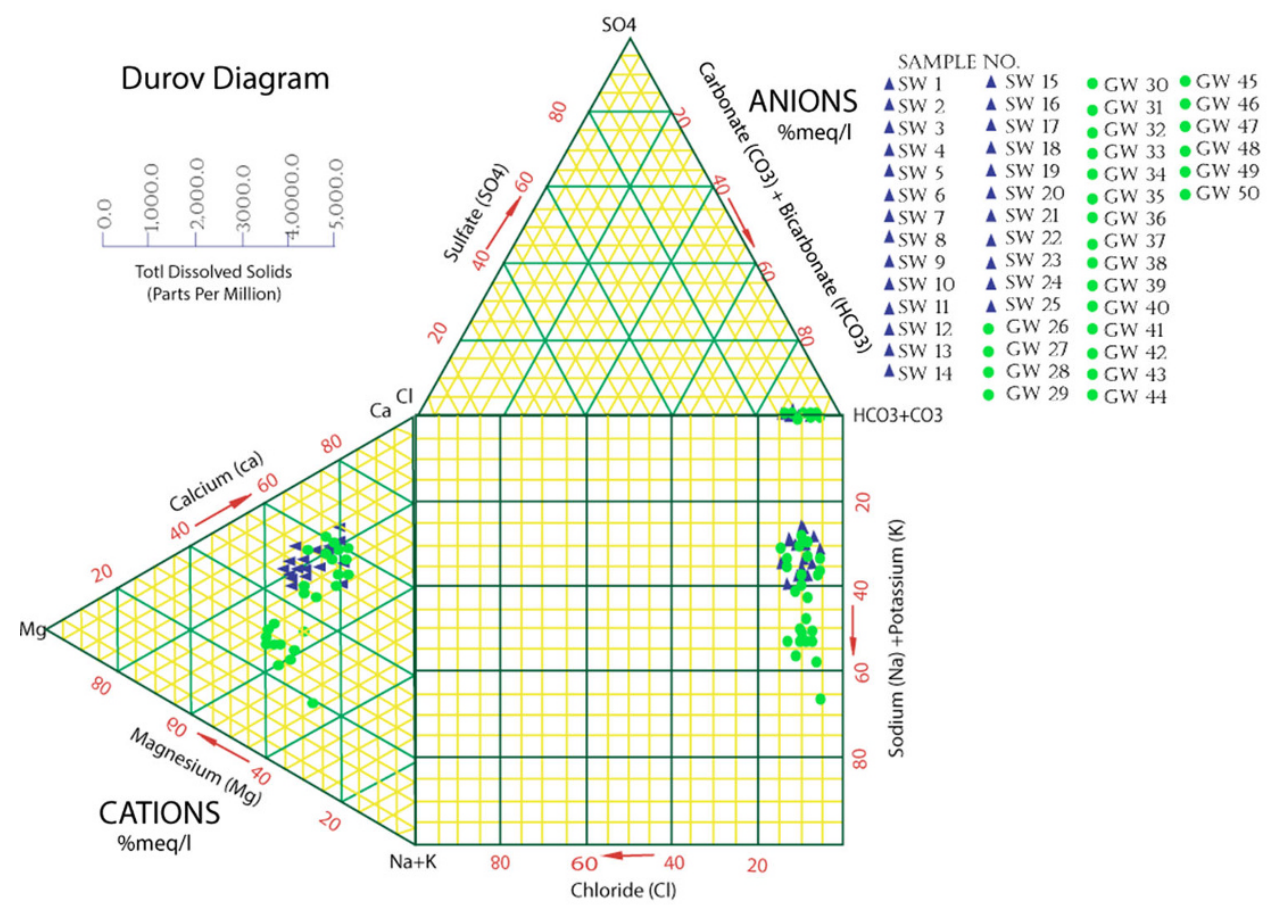

(b) Expanded Durov Diagram
Ramanathan 2008). The correlation matrices for physical parameters such as $\mathrm{pH}, \mathrm{EC}$, TDS and chemical parameters like major cations, $\mathrm{Ca}^{2+}, \mathrm{Na}^{+}, \mathrm{Mg}^{2+}, \mathrm{K}^{+}, \mathrm{Fe}^{\text {total }}$, and also the anions, $\mathrm{HCO}_{3}{ }^{-}, \mathrm{SO}_{4}{ }^{2-}, \mathrm{Cl}^{-}, \mathrm{CO}_{3}{ }^{2-}$, were computed, shown in Table 5. From Table 5, it can be confirmed that $\mathrm{pH}$ exhibits the negative correlation with $\mathrm{K}^{+}, \mathrm{Cl}^{-}$and $\mathrm{SO}_{4}^{-2}$ whereas with other parameters shows medium to less correlation. In the case of $\mathrm{EC}, \mathrm{pH}$ shows strong 
Table 4 Analyzed statistical parameters of the water samples around the BCM industry $(n=50)$

\begin{tabular}{lccccc}
\hline Water quality parameters & Minimum concentration & Maximum concentration & Mean & Standard deviation & Coefficient variation \\
\hline $\mathrm{pH}$ & 6.3 & 8.31 & 7.4744 & 0.422607 & 0.0565406 \\
$\mathrm{EC}(\mu \mathrm{s} / \mathrm{cm})$ & 69 & 626 & 320.22 & 171.308 & 0.534971 \\
$\mathrm{TDS}(\mathrm{mg} / \mathrm{L})$ & 44.16 & 400.64 & 204.941 & 109.637 & 0.534971 \\
$\mathrm{Na}^{+}(\mathrm{mg} / \mathrm{L})$ & 3.9 & 35.5 & 19.68 & 8.90469 & 0.452474 \\
$\mathrm{~K}^{+}(\mathrm{mg} / \mathrm{L})$ & 5.2 & 25.82 & 11.0986 & 3.8171 & 0.343926 \\
$\mathrm{Ca}^{2+}(\mathrm{mg} / \mathrm{L})$ & 6.1 & 78.2 & 51.758 & 22.2831 & 0.430525 \\
$\mathrm{Mg}^{2+}(\mathrm{mg} / \mathrm{L})$ & 5.3 & 32.09 & 16.064 & 5.88183 & 0.36615 \\
$\mathrm{Fe}^{\text {total }}$ & 0.75 & 1.5 & 1.192 & 0.192841 & 0.16178 \\
$\mathrm{Cl}^{-}(\mathrm{mg} / \mathrm{L})$ & 6.18 & 20.46 & 12.141 & 4.07855 & 0.335932 \\
$\mathrm{HCO}_{3}{ }^{-}(\mathrm{mg} / \mathrm{L})$ & 185.19 & 225.72 & 208.764 & 9.68846 & 0.0464088 \\
$\mathrm{CO}_{3}{ }^{2-}(\mathrm{mg} / \mathrm{L})$ & 2.500 & 11.25 & 7.3962 & 2.10196 & 0.284195 \\
$\mathrm{SO}_{4}{ }^{2-}(\mathrm{mg} / \mathrm{L})$ & 9.000 & 21.21 & 14.2226 & 3.00303 & 0.211145 \\
\hline
\end{tabular}

Table 5 Correlation coefficient matrix of water quality parameters $(n=50)$

\begin{tabular}{|c|c|c|c|c|c|c|c|c|c|c|c|c|}
\hline & $\mathrm{pH}$ & $\mathrm{EC}$ & TDS & $\mathrm{Na}^{+}$ & $\mathrm{K}^{+}$ & $\mathrm{Ca}^{2+}$ & $\mathrm{Mg}^{2+}$ & $\mathrm{Fe}^{\text {total }}$ & $\mathrm{Cl}^{-}$ & $\mathrm{HCO}_{3}{ }^{-}$ & $\mathrm{CO}_{3}{ }^{2-}$ & $\mathrm{SO}_{4}^{2-}$ \\
\hline $\mathrm{pH}$ & 1.0000 & & & & & & & & & & & \\
\hline EC & 0.1915 & 1.0000 & & & & & & & & & & \\
\hline TDS & 0.1915 & 1.0000 & 1.0000 & & & & & & & & & \\
\hline $\mathrm{Na}^{+}$ & 0.2882 & 0.7535 & 0.7535 & 1.0000 & & & & & & & & \\
\hline $\mathrm{K}^{+}$ & -0.3127 & -0.0924 & -0.0924 & -0.2884 & 1.0000 & & & & & & & \\
\hline $\mathrm{Ca}^{2+}$ & 0.5020 & 0.5887 & 0.5887 & 0.7355 & -0.3516 & 1.0000 & & & & & & \\
\hline $\mathrm{Mg}^{2+}$ & 0.2048 & 0.7305 & 0.7305 & 0.7928 & -0.3102 & 0.6562 & 1.0000 & & & & & \\
\hline $\mathrm{Fe}^{\text {total }}$ & 0.0143 & 0.0682 & 0.0682 & 0.1921 & -0.2520 & 0.2075 & 0.1962 & 1.0000 & & & & \\
\hline $\mathrm{Cl}^{-}$ & -0.0751 & 0.0338 & 0.0338 & 0.1237 & 0.1207 & 0.1125 & 0.0924 & 0.0652 & 1.0000 & & & \\
\hline $\mathrm{HCO}_{3}{ }^{-}$ & 0.2509 & 0.1231 & 0.1231 & 0.0859 & 0.0035 & 0.2816 & 0.1208 & -0.0760 & 0.1486 & 1.0000 & & \\
\hline $\mathrm{CO}_{3}{ }^{2-}$ & 0.0709 & 0.0202 & 0.0202 & 0.0242 & -0.0090 & 0.0069 & 0.2126 & 0.1165 & 0.0298 & 0.1809 & 1.0000 & \\
\hline $\mathrm{SO}_{4}{ }^{2-}$ & -0.1378 & -0.2046 & -0.2046 & -0.2877 & 0.3466 & -0.1483 & -0.1683 & -0.0285 & -0.0641 & -0.2927 & -0.1244 & 1.0000 \\
\hline
\end{tabular}

Bold values are significant at the $1 \%$ level

positive correlation with TDS. Here, the EC and TDS also reflect the high positive correlation with $\mathrm{Na}^{+}$and $\mathrm{Mg}^{2+}$ whereas $\mathrm{Ca}^{2+}$ exhibits the more than significant correlation with $\mathrm{pH}, \mathrm{EC}$ and TDS, and also high positive correlation with $\mathrm{Na}$. Moreover, $\mathrm{Na}-\mathrm{Mg}, \mathrm{Na}-\mathrm{Ca}$, and $\mathrm{Ca}-\mathrm{Mg}$ are the mentionable correlation pairs in the analysis. The $\mathrm{SO}_{4}^{-2}$ in the analysis specifies the positive correlation with $\mathrm{K}^{+}$only and negatively correlate with the other ions. The $\mathrm{K}^{+}$negatively correlated with $\mathrm{Ca}^{+2}$, $\mathrm{Mg}^{2+}, \mathrm{Fe}^{\text {total }}$ and $\mathrm{CO}_{3}{ }^{2-}$ whereas poorly correlated with $\mathrm{HCO}_{3}{ }^{-}, \mathrm{Cl}^{-}$and $\mathrm{SO}_{4}{ }^{2-}$ shown in Table 5. Figure 6 illustrates the correlation between concentrations of major ions and TDS around the study area. On the whole, $\mathrm{Ca}^{+2}$, $\mathrm{Mg}^{2+}, \mathrm{Fe}^{\text {total }}, \mathrm{HCO}_{3}^{-}, \mathrm{Cl}^{-}$and $\mathrm{CO}_{3}{ }^{2-}$ are positively correlated with TDS (Fig. 6a, c-g), whereas the correlation of $\mathrm{K}^{+}$and $\mathrm{SO}_{4}^{-2}$ to the TDS is negatively significant (Fig. 6b, h). In conclusion, on average a good positive correlation has been observed among relatively most of the parameters in the study area which implicates that such ions are derived from the same source of shallow recently recharged water like other flood plain areas of Bangladesh.

Assessment of water quality for livestock

The regular livestock around the mining area is cow, goat, sheep, duck, chickens and others of which principal sources of drinking water are canals, ponds, rivers and groundwater; hence, the qualitative assessment of such water sources are very much important in the area. The contaminated water body can have significant impacts on large volumes of water with miles of watercourse consequently which direct or indirect impact falls on different consumption sectors such as irrigation, livestock, industrial, aquatic lives 

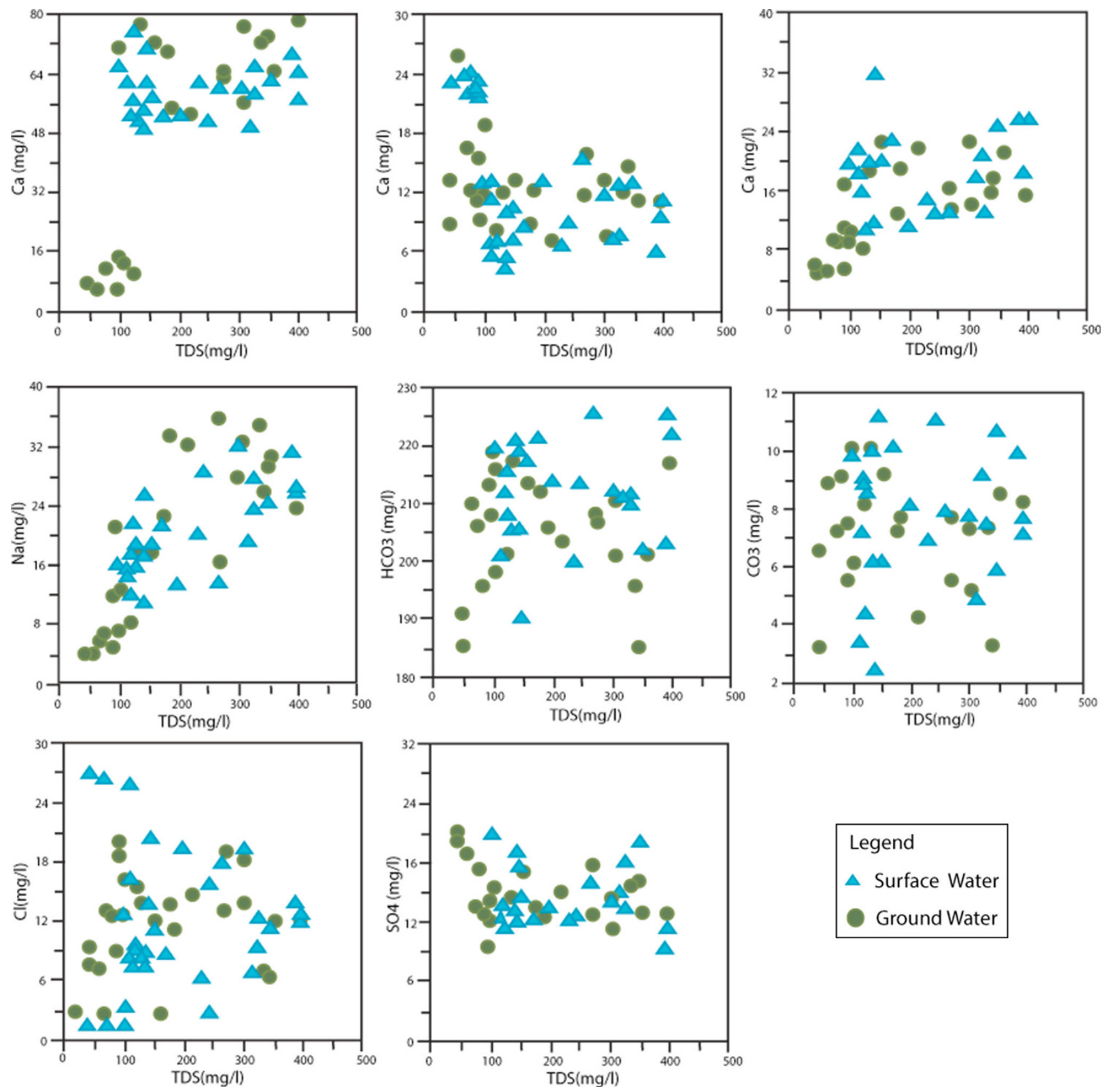

Fig. 6 a-h Hydrochemical correlations of $\mathrm{Ca}^{2+}, \mathrm{Cl}^{-}, \mathrm{CO}_{3}{ }^{2-}, \mathrm{HCO}_{3}{ }^{-}, \mathrm{K}^{+}, \mathrm{Mg}^{2+}, \mathrm{Na}^{+}$and $\mathrm{SO}_{4}{ }^{2-}$ contents vs. TDS

and so on. In the case of livestock, water should be of high quality to prevent them from various diseases, salt imbalance, or poisoning by toxic constituents (Bhardwaj and Singh 2011). As we know that human beings and livestock are subsisted closely in the environment where they follow almost the same guidelines for their water use, though most of the animals can drink water with moderately high dissolved solid (about $10 \mathrm{mg} / \mathrm{L}$ ) when $\mathrm{NaCl}$ is the chief constituent (Hossain et al. 2010). According to Ayers and Wescot (1985), the water having the salinity $<1,500 \mathrm{mg} / \mathrm{L}$ and $\mathrm{Mg}^{2+}<250 \mathrm{mg} / \mathrm{L}$ is suitable for drinking for most livestock. The excessive salinity in livestock drinking water can distress the animal's water balance and cause death, and also the higher levels of salinity and specific ions like $\mathrm{Mg}^{2+}$ in water can cause animal health problems and death (Bhardwaj and Singh 2011). Environmental Studies Board (1972) has suggested the upper limits of TDS concentration of water for livestock consumption shown in Table 6. However, the outcome of the present analysis shows that the TDS concentration ranges between 44.160 and $400.640 \mathrm{mg} / \mathrm{L}$, where the mean value is $204.941 \mathrm{mg} / \mathrm{L}$. Thus, from the upper limit of the TDS 
Table 6 Upper limit of TDS for livestock consumption with limit of TDS in the study area

\begin{tabular}{lrll}
\hline Livestock & $\begin{array}{l}\text { Upper } \\
\text { limit } \\
(\mathrm{mg} / \mathrm{L})\end{array}$ & $\begin{array}{l}\text { Limit of TDS in } \\
\text { the study area } \\
(\mathrm{mg} / \mathrm{L})\end{array}$ & \\
\hline Poultry & 2,860 & $44.160-400.640$ & $\begin{array}{l}\text { Well within the limit and } \\
\text { suitable for livestock } \\
\text { consumption }\end{array}$ \\
Pigs & 4,290 & & \\
Horses & 6,435 & & \\
Dairy cattle & 7,150 & & \\
$\begin{array}{l}\text { Beef cattle } \\
10,000\end{array}$ & & \\
$\begin{array}{l}\text { Lambs } \\
\text { (lamelling) }\end{array}$ & 12,900 & & \\
\hline
\end{tabular}

concentration in the surface and ground samples around the BCM area, this study implied that the water is suitable for livestock consumption.

\section{Evaluation of water quality for drinking}

To evaluate the aptness for drinking water and public health quality, the physical and chemical parameters of the groundwater as well as surface water were compared with the prescribed pattern recommended by the World Health Organization (WHO 1997) and Environmental Quality Standard for Bangladesh (EQS 1991) shown in Table 7. The table shows the maximum acceptable limit and maximum allowable limits of the water quality parameters. From this correlation Table 7, it can be concluded that $\mathrm{pH}$, TDS, $\mathrm{Ca}^{2+}, \mathrm{Mg}^{2+}, \mathrm{Na}^{+}, \mathrm{HCO}_{3}{ }^{-}, \mathrm{CO}_{3}{ }^{2-}, \mathrm{Cl}^{-}$and $\mathrm{SO}_{4}{ }^{2-}$ values of water samples from studied area belong to the standard limit which can be used for drinking purpose and public health without any risk. Besides, the concentration of $\mathrm{Fe}^{\text {total }}$ ranges from 0.75 to $1.50 \mathrm{mg} / \mathrm{L}$ and that of $\mathrm{K}^{+}$from 5.20 to $25.82 \mathrm{mg} / \mathrm{L}$ (Table 7). In the case of $\mathrm{Fe}^{\text {total }}$ concentration, about $88 \%$ of the water samples exceed the maximum allowable limit (WHO 1997) which indicates the fairly high concentrations of iron in the area. About 6 samples out of 50 water samples belong to the maximum acceptable limit of $0.3 \mathrm{mg} / \mathrm{L}$ (WHO 1997). The reasons for the high concentration of this constituent may be the removal of dissolved oxygen by organic matter leading to reduced conditions (Bhardwaj and Singh 2011). Under reducing conditions, the solubility of iron-bearing minerals (siderite, marcasite, etc.) increases which is leading to the enrichment of dissolved iron in the groundwater (White et al. 1991; Applin and Zhao 1989). This higher concentration of $\mathrm{Fe}^{\text {total }}$ in water is associated with imparting brownish to laundered clothing and causes staining of bathroom fittings and encrusting in water modes. Some of the water samples show high concentrations of $\mathrm{K}^{+}$. As much as $20(40 \%)$ out of 50 samples (Tables 2, 7) exceed the maximum allowable limit on suitability for drinking purpose and public health (WHO
1997; EQS 1991) which might be responsible for changing the taste of water from the normal to bitter taste in the area. $\mathrm{TH}$ of water is an another important parameter for evaluating the drinking water quality, though it has no recognized undesirable effect on the human body or others, but it may avert the formation of lather as well as raise the water normal boiling point. However, in the present study, the water has been categorized considering TH shown in Tables 8 and 3, which reflects that the TH ranges from 38.5 to $311.83 \mathrm{mg} / \mathrm{L}$ with an average of $175.17 \mathrm{mg} / \mathrm{L}$. As to the classification of TH, Sawyer and McCarty (1967) imply that $80 \%$ of water samples fit in the hard category, $4 \%$ in the medium and $16 \%$ in the soft category, respectively (Table 8). The high hardness in the mining area's water indicates the active hydraulic relation between surface and groundwater in the area. In fact, the high TH may cause encrustation on water supply distribution systems and also for durable utilization of hard water might escort to an increased the occurrence of different health dieses and disorder (Durvey et al. 1991).

\section{Evaluation of water quality for irrigation}

BCM locates thoroughly in the plain and cultivated land which is also surrounded by the same land morphology in the area. As we know that the mining operations directly interrupt the land morphology, soil fertility, water quality and other components of the environment. Thus, the present research assesses the quality of water bodies for irrigation purposes using $\mathrm{Na} \%, \mathrm{MH}, \mathrm{RSC}, \mathrm{SAR}$, PI and United States Department of Agriculture (USDA) classification. To have the highest crop efficiency, the excellent- to good-quality water is much necessary for irrigation purpose in everywhere. However, the aptness of water for irrigation is conditional on the effects of the mineral constituents of water on both the plant and soil (Bahar and Reza 2010). The each and every assessments regarding irrigation water quality must be linked to the assessment of the soils to be irrigated (Ayers and Wescot 1985). The disproportionate quantity of dissolved ions in irrigation water changes the physical and chemical properties of soil for plants and agricultural works consequently tumbling the production efficiency. Excess salinity reduces the osmotic activity of plants and thus interferes with the absorption of water and nutrients from the soil (Saleh et al. 1999). From Tijani (1994), the high sodium makes the soil hard which directly affects to trim down the permeability of soil. Sodium concentration and EC are very important in classifying irrigation water while the salts affecting the growth of plants directly also affect the soil structure permeability and aeration (Bhardwaj and Singh 2011). According to Raghunath (1987), the SAR value less than $10 \mathrm{meq} / \mathrm{L}$ is excellent for irrigation 
Table 7 Correlation between the water samples of the study area with the standard limits prescribed by WHO (1997) and EQS (1991) for drinking purposes and the resulting undesirable effects

\begin{tabular}{|c|c|c|c|c|c|c|}
\hline \multirow[t]{2}{*}{ Parameter } & \multirow[t]{2}{*}{ Unit } & \multicolumn{2}{|c|}{$\begin{array}{l}\text { WHO drinking water } \\
\text { standard WHO (1997) }\end{array}$} & \multirow{2}{*}{$\begin{array}{l}\text { EQS drinking } \\
\text { water EQS } \\
(1991) \\
\text { Min }^{\mathrm{m}}-\mathrm{Max}^{\mathrm{m}}\end{array}$} & \multirow{2}{*}{$\begin{array}{l}\text { Surface } \\
\text { groundwater in } \\
\text { the study area } \\
\text { Min }^{\mathrm{m}}-\text { Max }^{\mathrm{m}}\end{array}$} & \multirow[t]{2}{*}{ Undesirable effects } \\
\hline & & $\begin{array}{l}\text { Maximum } \\
\text { acceptable } \\
\text { limit }\end{array}$ & $\begin{array}{l}\text { Maximum } \\
\text { allowable } \\
\text { limit }\end{array}$ & & & \\
\hline $\mathrm{pH}$ & - & 6.5 & 8.5 & $6.5-8.5$ & $6.30-8.31$ & Some samples are below acceptable limits \\
\hline $\mathrm{EC}$ & $\begin{array}{l}\mu \mathrm{s} / \\
\mathrm{cm}\end{array}$ & - & - & - & $69.0-626.0$ & - \\
\hline TDS & $\begin{array}{c}\mathrm{mg} / \\
\mathrm{L}\end{array}$ & 500 & 1,500 & $500-1,500$ & $44.16-400.64$ & $\begin{array}{l}\text { All samples are below acceptable limit and have the normal } \\
\text { taste }\end{array}$ \\
\hline $\mathrm{Na}^{+}$ & $\underset{\mathrm{mg} /}{\mathrm{L}}$ & 200 & - & 200 & $3.90-35.50$ & All samples are within limits \\
\hline $\mathrm{K}^{+}$ & $\begin{array}{c}\mathrm{mg} / \\
\mathrm{L}\end{array}$ & - & 12 & 12 & $5.20-25.82$ & Bitter taste \\
\hline $\mathrm{Mg}^{2+}$ & $\mathrm{mg} /$ & 50 & 150 & $30-50$ & $5.30-32.09$ & All samples are within acceptable limits \\
\hline $\mathrm{Ca}^{2+}$ & $\begin{array}{c}\mathrm{mg} / \\
\mathrm{L}\end{array}$ & 75 & 200 & - & $6.10-78.20$ & Scale formation \\
\hline $\mathrm{Fe}^{\mathrm{total}}$ & $\mathrm{mg} /$ & 0.3 & 1 & $0.3-5$ & $0.75-1.50$ & $\begin{array}{l}\text { Some samples are within the standard range and some samples } \\
\text { are exceed the limit which can cause the staining of bathroom } \\
\text { fittings and also affects taste }\end{array}$ \\
\hline $\mathrm{Cl}^{-}$ & $\underset{\mathrm{mg} /}{\mathrm{m}}$ & 200 & 600 & $150-600$ & $6.18-20.46$ & All samples are within acceptable limits and have the salty taste \\
\hline $\mathrm{SO}_{4}^{2-}$ & $\mathrm{mg} /$ & 200 & 400 & 400 & $9.00-21.21$ & $\begin{array}{l}\text { All samples are below acceptable limit and have the laxative } \\
\text { effects }\end{array}$ \\
\hline $\mathrm{HCO}_{3}^{-}$ & $\begin{array}{c}\mathrm{mg} / \\
\mathrm{L}\end{array}$ & - & - & - & $185.19-225.72$ & - \\
\hline $\mathrm{CO}_{3}^{-}$ & $\underset{\mathrm{mg} /}{\mathrm{L}}$ & 45 & - & - & $2.50-11.25$ & All samples are below acceptable limits \\
\hline
\end{tabular}

purpose whilst these values greater that $26 \mathrm{meq} / \mathrm{L}$ is bad or unsuitable for irrigation. The total concentration of soluble salts in irrigation water can be categorized as low (EC $\leq 250 \mu \mathrm{S} / \mathrm{cm}), \quad$ medium $\quad(250-750 \mu \mathrm{S} / \mathrm{cm})$, high $(750-2,250 \mu \mathrm{S} / \mathrm{cm})$ and very high $(2,250-5,000 \mu \mathrm{S} / \mathrm{cm})$ (Raghunath 1987). The RSC values in water greater than $5 \mathrm{meq} / \mathrm{L}$ are considered harmful to the growth of plants, whereas the waters with RSC values above $2.5 \mathrm{meq} / \mathrm{L}$ are not considered suitable for irrigation purpose (Eaton 1950). According to the US Salinity Laboratory (1954), an RSC value less than $1.25 \mathrm{meq} / \mathrm{L}$ is safe for irrigation; a value between 1.25 and $2.5 \mathrm{meq} / \mathrm{L}$ is of marginal quality and a value more than $2.5 \mathrm{meq} / \mathrm{L}$ is unsuitable for irrigation. The $\mathrm{MH}>50$ is considered to be harmful and unsuitable for irrigation use (Szabolcs and Darab 1964). The PI is classified under class I $(>75 \%)$, class II $(25-75 \%)$ and class III $(<25 \%)$ orders. In the case of class I and class II, waters are grouped as good for irrigation with $75 \%$ or more of maximum permeability whereas class III waters are unsuitable with $25 \%$ of maximum permeability (Doneen 1964; WHO 1989).
However, in this study the TH, RSC, PI, SAR, Na\% and $\mathrm{MH}$ have been calculated (Table 3) following different empirical formulas shown in Eqs. 1, 2, 3, 4, 5 and 6, respectively. The sorting of water based on RSC values is summarized in Tables 3 and 7, where $100 \%$ surface water and $88 \%$ groundwater samples fall in the good categories besides only $12 \%$ of groundwater samples show the medium class, respectively, for irrigation purpose. The $\mathrm{Na} \%$ in the area ranges between 3.9 and $35.50 \%$; in groundwater samples, and $11.12-32.31 \%$ of surface water samples which indicate that the water is excellent to good in all cases for irrigation (Table 2). The Wilcox (1955) diagram relating Sodium percentage and total concentration shows that of all surface and groundwater samples fall in the excellent to good sections (Fig. 7) for irrigation. A high $\mathrm{Na} \%$ causes deflocculation and impairment of the tilth and permeability of soils (Karanth 1987). The laboratory data also plotted on the US salinity diagram (Fig. 8) which exemplify that all the water samples fall in the field of $\mathrm{C} 1$ and $\mathrm{C} 2-\mathrm{S} 1$ indicate good-quality water of medium-high salinity with low 
Table 8 Classification of water around the mining area based on different parameters such as TDS, Na\%, EC, SAR, PI, RSC, MH and $\mathrm{TH}$

\begin{tabular}{|c|c|c|c|}
\hline Classification scheme & Categories & Ranges & $\begin{array}{l}\text { Percent of } \\
\text { samples }\end{array}$ \\
\hline \multirow[t]{4}{*}{$\begin{array}{l}\text { TDS (Davis and } \\
\text { DeWiest 1966) }\end{array}$} & $\begin{array}{l}\text { Desirables for } \\
\text { drinking }\end{array}$ & $<500$ & 100 \\
\hline & $\begin{array}{l}\text { Permissible for } \\
\text { drinking }\end{array}$ & $500-1,000$ & Nil \\
\hline & $\begin{array}{l}\text { Useful for } \\
\text { irrigation }\end{array}$ & $1,000-3,000$ & Nil \\
\hline & $\begin{array}{l}\text { Unfit for } \\
\text { drinking and } \\
\text { irrigation }\end{array}$ & $>3,000$ & Nil \\
\hline \multirow{4}{*}{$\begin{array}{l}\text { TDS (Freeze and } \\
\text { Cherry 1979) }\end{array}$} & Fresh water type & 1,000 & 100 \\
\hline & $\begin{array}{l}\text { Brackish water } \\
\text { type }\end{array}$ & $1,000-10,000$ & Nil \\
\hline & $\begin{array}{l}\text { Saline water } \\
\text { type }\end{array}$ & $10,000-100,000$ & Nil \\
\hline & Brine water type & $>100,000$ & Nil \\
\hline \multirow[t]{5}{*}{ Na\% (Wilcox 1955) } & Excellent & $<20$ & 52 \\
\hline & Good & $20-40$ & 48 \\
\hline & Permissible & $40-60$ & Nil \\
\hline & Doubtful & $60-80$ & Nil \\
\hline & Unsuitable & $>80$ & Nil \\
\hline \multirow[t]{2}{*}{$\mathrm{Na} \%$ (Eaton 1950) } & Safe & $<60$ & 100 \\
\hline & Unsafe & $>60$ & Nil \\
\hline \multirow{3}{*}{$\begin{array}{l}\text { Electrical } \\
\text { conductivity (EC) }\end{array}$} & Permissible & $<1,500$ & 100 \\
\hline & Not permissible & $1,500-3,000$ & Nil \\
\hline & Hazardous & $>3,000$ & Nil \\
\hline \multirow{5}{*}{$\begin{array}{l}\text { Salinity hazard EC } \\
(\mu \mathrm{s}) \text { (Raghunath } \\
\text { 1987) }\end{array}$} & Excellent & $<250$ & 50 \\
\hline & Good & $250-750$ & 50 \\
\hline & Medium & $750-2,250$ & Nil \\
\hline & $\mathrm{Bad}$ & $2,250-4,000$ & Nil \\
\hline & Very bad & $>4,000$ & Nil \\
\hline \multirow[t]{4}{*}{ SAR (Richards 1954) } & Excellent & $<10$ & 100 \\
\hline & Good & $10-18$ & Nil \\
\hline & Doubtful & $18-26$ & Nil \\
\hline & Unsuitable & $>26$ & Nil \\
\hline \multirow[t]{3}{*}{ PI (Doneen 1964) } & Class-I & $>75$ & 94 \\
\hline & Class-II & $25-75$ & Nil \\
\hline & Class-III & $<25$ & 6 (groundwater) \\
\hline \multirow[t]{3}{*}{ RSC (Richards 1954) } & Good & $<1.25$ & 82 \\
\hline & Medium & $1.25-2.5$ & 12 (groundwater) \\
\hline & $\mathrm{Bad}$ & $>2.5$ & 4 (groundwater) \\
\hline \multirow{2}{*}{$\begin{array}{l}\text { MH (Szabolcs and } \\
\text { Darab 1964) }\end{array}$} & Suitable & $<50$ & 90 \\
\hline & $\begin{array}{c}\text { Harmful and } \\
\text { unsuitable }\end{array}$ & $>50$ & 10 (groundwater) \\
\hline \multirow[t]{4}{*}{$\begin{array}{l}\text { TH (Sawyer and } \\
\text { McCarty 1967) }\end{array}$} & Soft & $<75$ & $\begin{array}{l}16 \\
\text { (groundwater) }\end{array}$ \\
\hline & Moderately hard & $75-150$ & 4 (groundwater) \\
\hline & Hard & $150-300$ & 80 \\
\hline & Very hard & $>300$ & Nil \\
\hline
\end{tabular}

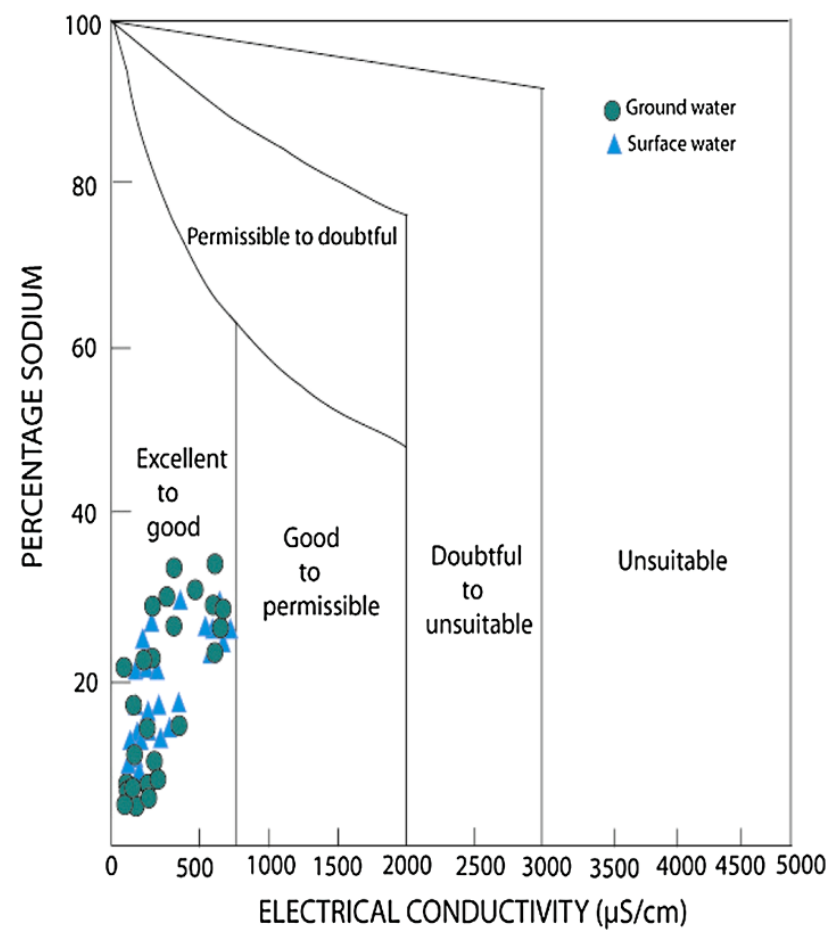

Fig. 7 Suitability of irrigation water based on EC and $\mathrm{Na} \%$ (after Wilcox 1955)

SAR value, which might be recommended for irrigation use without any salinity or alkalinity hazard. Moreover, the suitability of surface and groundwater for irrigation has been assessed based on PI (Table 3) values while the soil permeability is affected by the long-term use of irrigation water as it is influenced by $\mathrm{Na}^{+}, \mathrm{Ca}^{2+}, \mathrm{Mg}^{2+}$ and $\mathrm{HCO}_{3}{ }^{-}$content of the soil (Ramesh and Elango 2011). In this research, the PI values have been plotted on the Doneen's Chart (Fig. 9) which reflects that all of the water samples of the studied area fall into the class-I, except three groundwater samples, which implies that the water is of good quality for irrigation purposes with $75 \%$ or more of maximum permeability. However, three groundwater water samples fit into class III and so unsuitable for the irrigation. Thus, considering the all of the characteristics discussed above, it can be concluded that the surface and groundwater are excellent with good quality for irrigation use around the mining area.

Future environmental implications

Mining operations affect water resources both surface and groundwater at various stages of the life cycle of the mine and even after its closure. The mining process itself, mineral processing operations, mine dewatering, seepage of 


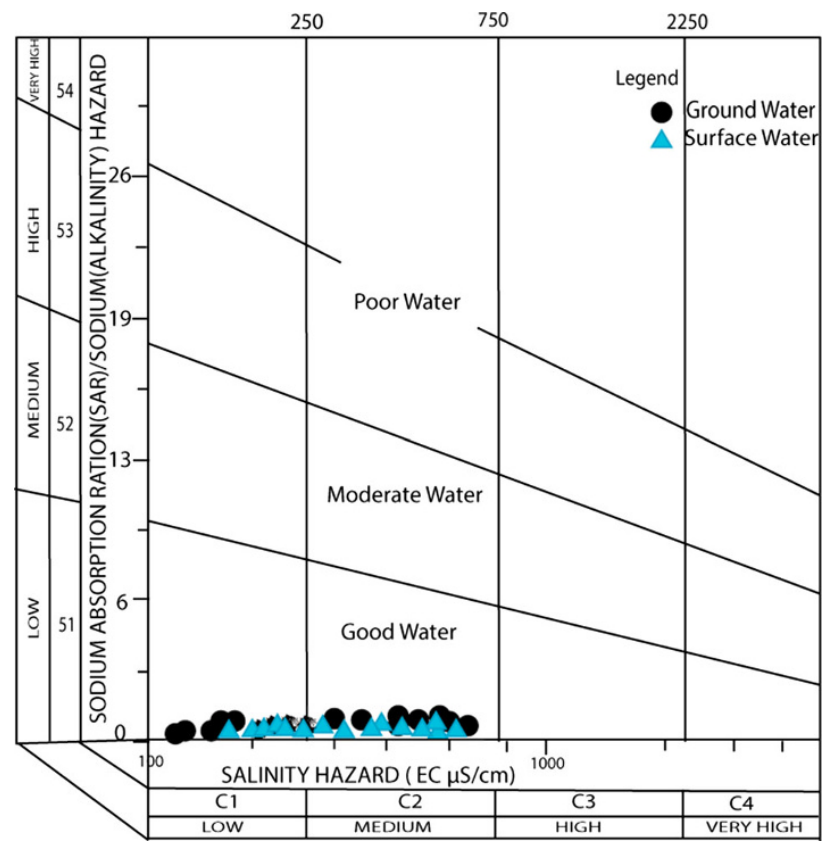

Fig. 8 US salinity diagram for classification of irrigation waters (after Richards 1954)

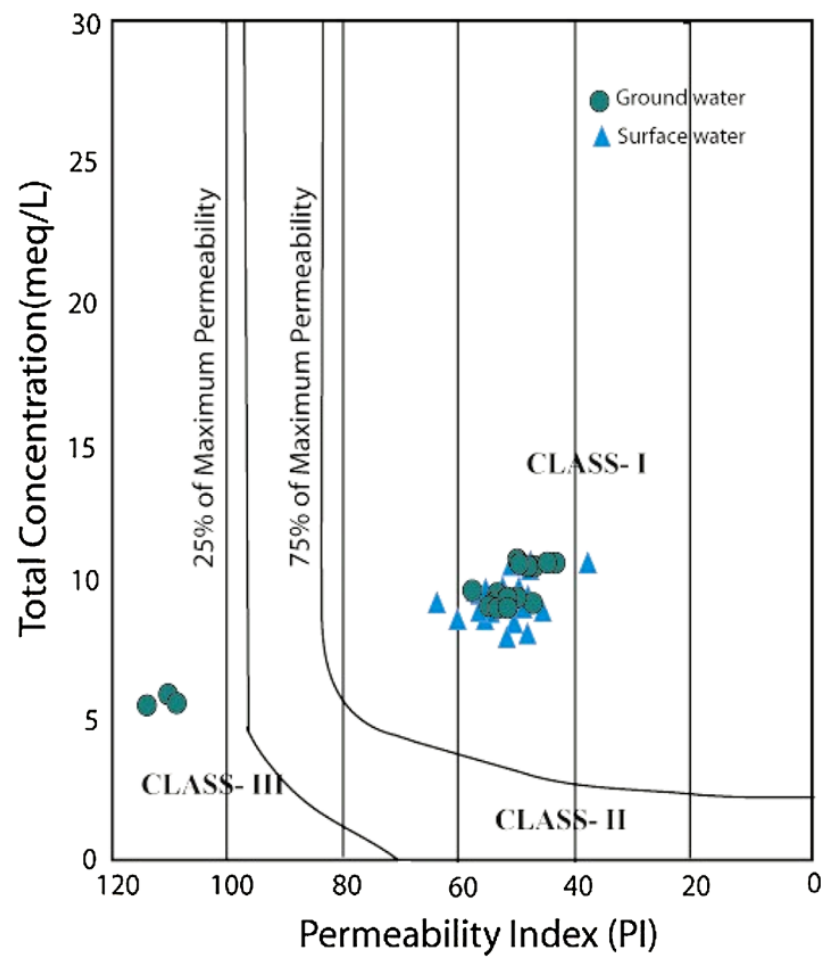

Fig. 9 Classification of irrigation water based on PI (after Doneen 1964)

contaminated leaches, flooding of mine workings and discharge of untreated water are some important processes with related mine water problems (Younger et al. 2002). Surface mining inevitably produces major environmental disturbances since vegetation; top soil and underlying soil mantle have to be removed to gain access to the minerals beneath. In underground mining, large quantities of waste are produced, which commonly exceed the volume of minerals (Younger 1997). In mining practices, numerous categories of wastes are produced which possibly turn into ultimately the causes of environmental pollution. In the case of raw material grinding, ore refining and solid waste to the environment (Adriano et al. 2004), enormous solid wastes with high risks to acid generation and heavy metal leaching may cause contamination of surface water and groundwater during mining operation or even long after mine closure (Changul et al. 2010; Conesa et al. 2007). Mining industrial wastes containing various hazardous materials may be dangerous to contaminate the water, soil and air, and can affect human health as well the surrounding environment as a whole (Paldyna et al. 2012). Human activities such as industrialization, mining and urbanization may also alter the water quality by polluting the environment (Banks et al. 1997). Among the solid wastes, tailings are one of the highest worrisome, particularly when they have low $\mathrm{pH}$ and high concentrations of heavy metals (Shu et al. 2001). In the case of changing $\mathrm{pH}$, they can affect aquatic life indirectly by altering other aspect of water chemistry. Low $\mathrm{pH}$ levels accelerate the release of heavy metals from sediments on the stream/pond bottom that can reduce the chance of survival of most aquatic organisms. From these discussions it is apparent that the mining processes might have a great role to degrade the environmental quality including water environment. However, from the laboratory analysis of the present research, it can be implied that there are no significant parameters or factors found in the water, which are much badly effective on the environment around the area. The water quality in the area is reasonably good for livestock, drinking, domestic, irrigation as well as ecosystems which are consistent with Howladar (2012) and Uddin (2003) research. Based on the different classifications, interpretation such as TDS, Na\%, EC, SAR, PI, RSC, MH and $\mathrm{TH}$, the majority of water samples and their parameters are belonging to the standard given by WHO international guideline and EQS standards. Few of parameters such as $\mathrm{Fe}^{\text {total }}$ and $\mathrm{K}^{+}$show higher concentration than the standard limit which probably to some extent is harmful to the environment for present as well as future. In other cases, the higher TH $(150-300 \mathrm{mg} / \mathrm{L})$ of the water is the other indicator for water and environmental degradation while there is some suggestive evidence that long-term consumption of hard water might lead to an increased incidence of urolithiasis, anencephaly, pre-natal mortality, some types of cancer and cardiovascular disorders (Agrawal and Jagetai 1997; Durvey et al. 1991). Moreover to have better implication about water environment around 
this area, further study on the present concentration of environmentally significant trace elements such as $\mathrm{Ag}, \mathrm{Cr}$, $\mathrm{Co}, \mathrm{As}, \mathrm{Cu}, \mathrm{Cd}, \mathrm{Ni}, \mathrm{Pb}, \mathrm{Tl}$ and $\mathrm{Zn}$ in the water is strongly recommended to evaluate for future safe and sound environment.

\section{Conclusions}

The suitability of surface and groundwater for livestock, drinking, irrigation purposes and environmental implications has been evaluated based on different guides and established standards around the BCM Industry, Dinajpur, Bangladesh. The chemical analyses' results for the major cations and anions of 25 surface and 25 groundwater samples collected from the mining and its probable contiguous virgin area are presented. The quality of water analysis is presented by the estimation of TDS, $\mathrm{pH}, \mathrm{EC}, \mathrm{Ca}^{2+}, \mathrm{Mg}^{2+}$, $\mathrm{K}^{+}, \mathrm{Na}^{+}, \mathrm{CO}_{3}{ }^{2-}, \mathrm{HCO}_{3}{ }^{-}, \mathrm{SO}_{4}{ }^{2-}$ and $\mathrm{Cl}^{-}$. Consequently, water classification-related indices, for examples $\mathrm{TH}, \mathrm{Na} \%$, salinity hazard, SAR, RSC, MH and PI, were estimated. The concentrations of major ions in surface and groundwater are within the tolerable limit for livestock, drinking, and irrigation uses where the order of cations and anions concentration is $\mathrm{Ca}^{2+}>\mathrm{Na}^{+}>\mathrm{Mg}^{2+}>\mathrm{K}^{+}>\mathrm{Fe}^{\text {total }}$ and $\mathrm{HCO}_{3}{ }^{-}>\mathrm{SO}_{4}{ }^{2-}>\mathrm{Cl}^{-}>\mathrm{CO}_{3}{ }^{2-}$, respectively. In the study, the Piper's Trilinear diagram and Expanded Durov diagram reveal that two dominant types of hydrochemical facies which are $\mathrm{Ca}^{2+}-\mathrm{HCO}_{3}{ }^{-}$and $\mathrm{Mg}^{2+}-\mathrm{HCO}_{3}{ }^{-}$are consistent with the local and regional water types. The mean TDS value is $204.941 \mathrm{mg} / \mathrm{L}$, which reflects that the both source of water can be used for livestock consumption without any risks. In the case of $\mathrm{Fe}^{\text {total }}$ and $\mathrm{K}^{+}$concentration, 88 and $40 \%$ of the water samples, respectively, exceed the maximum $\mathrm{WHO}$ and $\mathrm{EQS}$ allowable limit for drinking purpose and public health whereas others ions are thoroughly within the limits for drinking use. The $\mathrm{MH}$ of all water samples exhibits the suitable condition for drinking purpose, whereas the calculated TH reveals that $80 \%$ water belongs to the hard category which might be suggestive for not using this surface or ground water for a long time without proper treatment and having to ample plan to overcome this harm for irrigation, drinking or any other purposes timely. The Na\%, MH, RSC, SAR and PI concentrations indicate that almost all of the samples are excellent to good for irrigation uses. Moreover, the statistical applications signify that most of the ions are positively correlated and not so deviates their mean value from each other which should be the signatures of the same water source in the area. Overall, surface and groundwater around the coal-mining industrial area ruins compatible and no noticeable environmental degradation observed except few cases around the area. Thus, considering the case of increasing concentrations of some water parameters such as $\mathrm{Fe}^{\text {total }}, \mathrm{K}^{+}$and $\mathrm{TH}$ with their possible relation to environmental contamination, this research suggests that water quality monitoring program should be performed in every 6-month interval or less and also taking the necessary precautionary measures for preventing the future degradation of water quality in this region which might play the key role to protect the green and clean environment and fruitful coal-mining operations around the industry as well as in the country.

Acknowledgments Firstly, the authors are very thankful to Professor Dr. Abdulrahman I. Alabdulaaly, Editor-in-Chief for his kind co-operation regarding the encouraging review processes, advice and publication of the research. Secondly, they are cordially thankful to the anonymous reviewers for their critical evaluation and final suggestion to publish this research. Moreover, the financial assistance from Ministry of Science and Technology, Government of Bangladesh, Dhaka is highly acknowledged (Project Grant No: 39.009.006.01.00.042.2012-2013/EAS-4/579) otherwise this research was entirely unattainable.

Open Access This article is distributed under the terms of the Creative Commons Attribution License which permits any use, distribution, and reproduction in any medium, provided the original author(s) and the source are credited.

\section{References}

Adriano DC, Wenzel WW, Vangronsveld J, Bolan NS (2004) Role of assisted natural remediation in environmental cleanup. Geoderma 22:121-142

Agrawal V, Jagetai M (1997) Hydrochemical assessment of groundwater quality in Udaipur city, Rajasthan, India. In: Proceedings of national conference on dimensions of environmental stress in India, Department of Geology, Baroda, India

Ahmed SA et al. (2000) Arsenic: water contamination and health hazard. pp 7-62

Alam M, Alam MM, Curray J, Chowdhury RMLR, Gani MR (2003) An overview of the sedimentary geology of the Bengal basin in relation to the regional tectonic framework and basin-fifill history. Sediment Geol 155:179-208

Alam JB, Ahmed AAM, Khan MJH, Ahmed B (2011) Evaluation of possible environmental impacts for Barapukuria thermal power plant and coal mine. J Soil Sci Environ Manag 2(5):126-131

APHA (1995) Standard methods for the examination of water and wastewater. 19th edn. Washington

Applin KR, Zhao N (1989) The kinetics of Fe(II) oxidation and well screen encrustation. Ground Water 27:168-174

Arumugam K, Elangovan K (2009) Hydrochemical characteristics and groundwater quality assessment in Tirupur region, Coimbatore district, Tamil Nadu, India. Environ Geol 58(7):1509-1520

Ayers RS, Wescot DW (1985) Water quality for irrigation. FAO irrigation and Drainage. Paper no. 20, review 1, FAO, Rome

Bahar MM, Reza MS (2010) Hydrochemical characteristics and quality assessment of shallow groundwater in a coastal area of southwest Bangladesh. Environ Earth Sci 61:1065-1073. doi:10. 1007/s12665-009-0427-4

Bakr AM, Rahman QMA, Islam MM, Islam MK, Uddin MN, Resan SA, Haider MJ, Islam MS, Ali MW, Chowdhury M, Mannan KH, Anam ANMH (1996) Geology and coal deposit of 
Barapukuria basin, Dinajpur district, Bangladesh. Records of the Geological Survey of Bangladesh 8(1):36

Banks D, Younger PL, Arnesen RT, Iversen ER, Banks SB (1997) Mine water chemistry: the good, the bad and the ugly. Environ Geol 32:157-174

Bhardwaj V, Singh DS (2011) Surface and groundwater quality characterization of Deoria district, Ganga plain, India. Environ Earth Sci 63:383-395. doi:10.1007/s12665-010-0709-x

Bian Z, Lei S, Inyang H, Chang L, Zhang R, Zhou Q, He X (2009) Integrated method of RS and GPR for monitoring the changes in the soil moisture and groundwater environment due to underground coal mining. Environ Geol 57:131-142

Burden DJ, Mazloum S (1965) Some chemical types of groundwater from Syria, UNESCO symposium, Tehran. UNESCO, Paris, pp 73-90

Burns SS (2005) Bringing down the mountains: the impact of mountaintop removal surface coal mining on southern West Virginia communities (1970-2004). Dissertation, West Virginia University

Changul C, Sutthirat C, Padmanahban G, Tongcumpou C (2010) Chemical characteristics and acid drainage assessment of mine tailings from Akara gold mine in Thailand. Environ Earth Sci 60:1583-1595. doi:10.1007/s12665-009-0293-0

CMC (1994) Preliminary geology and exploration report of Barapukuria coal mine, Bangladesh

Conesa HM, Garcia G, Faz A, Arnaldos R (2007) Dynamics of metal tolerant plant communities development in mine tailings from the Ena-La union mining district (SE Spain) and their interest for further revegetation purposes. Chemosphere 68:1180-1185

Davis A (1981) Sulfur in coal: earth and mineral sciences, Pennsylvania State University, University Park 51(2)

Davis SN, DeWiest RJ (1966) Hydrogeology. Wiley, New York

Davis CE, Duffy RJ (2009) King coal vs. reclamation federal regulation of mountaintop removal mining in Appalachia. Admin Soc 41:674-692

Davis J, Exley C (1992) Hydrochemical character of the main aquifer units of central and north-eastern Bangladesh and possible toxicity of groundwater to fish and humans. final report, British geol survey, technical report. WD/92/43R

Davis JM, Lohmann RC, Phillips FM, Wilson JL, Love DW (1993) Architecture of the Sierra Ladrones formation, Central New Mexico: depositional controls on the permeability correlation structure. Geol Soc Am Bull 105(8):998-1007

Desikacher SV (1974) A review of the tectonic and geological history of eastern India in terms of plate tectonic theory. J Geol Soc India 15:134-149

Dinelli E, Lucchini F, Fabbri M, Cortecci Z (2001) Metal distribution and environmental problems related to sulfide oxidation in the Libiola copper mine area (Ligurian Apennines, Italy). J Geochem Explor 74:141-152. doi:10.1016/S0375-6742(01)00180-7

Dold B, Fontboté L (2002) A mineralogical and geochemical study of element mobility in sulfide mine tailings of $\mathrm{Fe}$-oxide $\mathrm{Cu}-\mathrm{Au}$ deposits from the Punta Del Cobre belt, Northern Chile. J Chem Geol 189:135-163

Doneen LD (1964) Water quality for agriculture. Department of Irrigation, University of Calfornia, Calfornia, p 48

Durvey VS, Sharma LL, Saini VP, Sharma BK (1991) Handbook on the methodology of water quality assessment. Agriculture University, Rajasthan

Eaton FM (1950) Significance of carbonate in irrigation waters. Soil Sci 69:123-133

Environmental Studies Board (1972) Water quality criteria. National Academy of Science, National Academy of Engineering

EQS (1991) Environmental quality standards. Department of Environment, Bangladesh

Foster DR, Motzkin G, Slater B (1998) Land use history as long term broad scale disturbance: regional forest dynamics in central New England. Ecosystems 1:96-119
Freeze RA, Cherry JA (1979) Groundwater. Prentice Hall, Englewood Cliffs

Hawkins JW (1984) Iron di-sulfide characteristics of the Waynesburg, Redstone, and Pittsburgh coals in West Virginia and Pennsylvania. Dissertation, West Virginia University

Hossain G, Howladar MF, Nessa L, Ahmed SS, Quamruzzaman C (2010) Hydrochemistry and classification of groundwater resources of Ishwardi municipal area, Pabna district, Bangladesh. Geotech Geol Engg 28(5):671-679

Hounslow AW (1995) Water quality data: analysis and interpretation. Oklahoma State University, Oklahoma, pp 24-90

Howladar MF (2012) Coal mining impacts on water environs around the Barapukuria coal mining area, Dinajpur, Bangladesh. Environ Earth Sci 70(1):215-226. doi:10.1007/s12665-012-2117-x

Hudson EKA, Macklin MG, Taylor MP (1999) 2000 years of sediment-borne heavy metal storage in the Yorkshire Ouse basin, NE England, UK. Hydrol Process 13:1087-1102

Islam MR (2009) Origin of the regional stress field along the Liquine Ofqui fault zone (LOFZ), Southern Chilean Andes by means of FE simulation. J Mt Sci 6:1-13

Islam MR, Islam MS (2005) Water inrush hazard in Barapukuria coal mine, Bangladesh. Bangladesh J Geol 24:1-17

Karanth KR (1987) Groundwater assessment, development and management. Tata McGraw-Hill, New Delhi

Khan FH (1991) Geology of Bangladesh. Willey Eastern Ltd, New Delhi, pp 33-40

Khan AA, Chouhan RKS (1996) The crustal dynamics and the tectonic trends in the Bengal basin. J Geodyn 22:267-286

Khan AA, Rahman T (1992) An analysis of gravity field and tectonic evaluation of the north-western part of Bangladesh. Tectonophysics 206:351-364

Krekeler MPS, Kearns LE (2008) A new locality of Palygorskiterich clay from the south-eastern Yucatan: a potential material source from environmental applications. Environ Geol 58(4):715-726

Lloyd IW (1965) The hydrochemistry of the aquifers of north-eastern Jordan. J Hydrol 3(3-4):319-330

Lloyd JW, Heathcote JA (1985) Natural inorganic hydrochemistry in relation to groundwater: an introduction. Claredon Press, Oxford, p 291

MacMillan A, Preston D, Wolfe J, Yu S (2007) Basic statistics: mean, median, average, standard deviation, z-scores, and $\mathrm{p}$-value. Retrieved from: https://controls.engin.umich.edu/wiki/index.php/ Basic_statistics:_mean,_median,_average,_standard_deviation,_zscores,_and_p-value

Meck M, Love D, Mapani B (2006) Zimbabwean mine dumps and their impacts on river water quality: a reconnaissance study. Phys Chem Earth 31:797-803

Mostofa GAKM (2002) A comparative study of long wall slicing method by filling or non-filling of caved area of the Barapukuria coal mining project, Dinajpur, Bangladesh. Dissertation, University of Rajshahi

Ophori DU, Toth J (1989) Patterns of groundwater chemistry, Ross Creek Basin, Alberta, Canada. Groundwater 27:20-26

Paldyna J, Krasnodebska OB, Kregielewska K, Kowalska J, Jedynak L, Golimowski J, Grobelski T, Farbiszewska KJ, Farbiszewska T (2012) The assessment of environmental pollution caused by mining and metallurgy wastes from highly polluted postindustrial regions in southern Poland. Environ Earth Sci. doi: $10.1007 / \mathrm{s} 12665-012-1750-8$

Palmer MA, Bernhardt ES, Schlesinger WH, Eshleman KN, Foufoula GE, Hendryx MS, Lemly AD, Likens GE, Loucks OL, Power ME, White PS, Wilcock MA (2010) Mountain top mining consequences. Sci 327. doi:10.1126/science.1180543

Piper AM (1953) A graphic procedure in the chemical interpretation of water analysis. US geological survey groundwater, note 12 
Raghunath HM (1987) Groundwater. Wiley Eastern Ltd, New Delhi

Ramesh K, Elango L (2011) Groundwater quality and its suitability for domestic and agricultural use in Tondiar river basin, Tamil Nadu, India. Environ Monit Assess. doi:10.1007/s10661-0112231-3

Ribet I, Ptacek CJ, Blowes DW, Jambor JL (1995) The potential for metal release by reductive dissolution of weathered mine tailings. J Contam Hydrol 17:239

Richards LA (1954) Diagnosis and improvement of saline and alkali soils. US Department of Agriculture Hand Book, no 60

Saleh A, Al-Ruwaih F, Shehata M (1999) Hydrogeochemical processes operating within the main aquifers of Kuwait. J Arid Environ 42:195-209

Sawyer GN, McCarty DL (1967) Chemistry of sanitary engineers, 2nd edn. McGraw-Hill, New York, p 518

Sawyer GN, McMcartly DL, Parkin GF (2003) Chemistry for environmental engineering and science, 5th edn. McGraw Hill, New York, p 152

Schellenbach WL, Krekeler MPS (2012) Mineralogical and geochemical investigations of pyrite-rich mine waste from a kyanite mine in central Virginia with comments on recycling. Environ Earth Sci 66:1295-1307

Schoeller H (1965) Qualitative evaluation of groundwater resources. In: Methods and techniques of groundwater investigations and development. UNESCO, Paris, pp 54-83

Shu WS, Ye ZH, Lan CY, Zhang ZQ, Wong MH (2001) Acidification of $\mathrm{Pb} / \mathrm{Zn}$ mine tailings and its effect on heavy metal mobility. Environ Int 26:389-394

Srivastava SK, Ramanathan AL (2008) Geochemical assessment of groundwater quality in vicinity of Bhalswa landfill, Delhi, India using graphical and multivariate statistical methods. Environ Geol 53:1509-1528

Szabolcs I, Darab C (1964) The influence of irrigation water of high sodium carbonate content of soils. In: Proceedings of 8th international congress issue transactions vol 2, pp 803-812

Tijani MN (1994) Hydrochemical assessment of groundwater in Moro area, Kwara state, Nigeria. Environ Geol 24:194-202

Todd DK (1980) Groundwater hydrology, 2nd edn. Willey, New York, p 70

US Salinity Laboratory Staff (1954) Diagnosis and improvement of saline and alkalis soils. US Department of Agriculture handbook, vol 60, p 160
Uddin MK (2003) Chemistry of drainage water from the Barapukuria coal mine, Bangladesh: Its suitability for utilization. Dissertation, University of Rajshahi

Uddin MN, Islam MS (1992) Gondwana basins and their coal resources in Bangladesh, geology in south Asia-1. In: Proceedings of 1st South Asian geological congress, Pakistan pp 224-230

Walton WC (1970) Groundwater resource evaluation. McGraw-Hill, New York

Wardell A (1991) Techno-economic feasibility study, Barapukuria coal project, Dinajpur district, Bangladesh. vol 1, 2

White AF, Benson SM, Yee AW, Woolenberg HA, Flexser S (1991) Groundwater contamination at the Kesterson reservoir, California: geochemical parameters influencing selenium mobility. Water Resour Res 27:1085-1098

WHO (1989) Health guidelines for the use of wastewater in agriculture and aquaculture. In: Report of a WHO scientific group: technical report series, WHO, Geneva, pp 778

WHO (1997) Guidelines for drinking water quality, vol 1. World Health Organization, Geneva

WHO (2011) Guidelines for drinking water quality, 4th edn. World Health Organization, Geneva

Wilcox LV (1955) Classification and use of irrigation water. US Department of Agriculture, Circ 696, Washington DC

Yangui H, Abidi I, Zouari K, Rozanski K (2012) Deciphering groundwater flow between the complex terminal and plioquaternary aquifers in Chott Gharsa plain (south-western Tunisia) using isotopic and chemical tools. Hydrolog Sci J pp 1-18. doi:10.1080/02626667.2012.689110

Younger PL (1997) The longevity of mine water pollution: a basis for decision-making. Sci Total Environ 194(195):457-466

Younger PL, Banwart SA, Hedin RS (2002) Environmental Pollution: Mine water, hydrology, pollution, remediation. Kluwer Academic Publishers, Dordrecht, Netherlands, pp 442

Zaher MA, Rahman A (1980) Prospects and investigations for mineral in northern part of Bangladesh. Petroleum and mineral resource of Bangladesh, seminar and exhibition, Dhaka 